\title{
Human Medullary Thyroid Carcinoma: Characterization of the Serotonergic and Neuronal Properties of a Neurectodermally Derived Cell Line
}

\author{
Hadassah Tamir, ${ }^{1,2}$ Kuo-peing Liu, ${ }^{1}$ Robert F. Payette, ${ }^{2}$ Shu-chi Hsiung, ${ }^{1}$ Mella Adlersberg, ${ }^{1}$ Eladio A. Nunez, ${ }^{2}$ \\ and Michael D. Gershon ${ }^{2}$ \\ 'Division of Neuroscience, New York State Psychiatric Institute, New York, New York 10032, and 2Department of Anatomy \\ and Cell Biology, Columbia University, College of Physicians and Surgeons, New York, New York 10032
}

Parafollicular (PF) cells have been found to be a good model system for the study of serotonergic cellular mechanisms relevant to neurons. PF cells are derived from the same region of the neural crest that gives rise to the neurons of the gut and are capable of extending neurofilament-bearing neuritic processes. PF cells also synthesize 5-hydroxytryptamine (5-HT) and costore 5-HT in the same vesicles as the specific 5-HT-binding protein, $45 \mathrm{kDa}$ SBP. A hypothesis has been advanced that PF cells and enteric neurons share a common developmental precursor. The present investigation was undertaken in order to determine whether a human medullary thyroid carcinoma (MTC) cell line, which is derived from PF cells, sufficiently mimics PF cells that it can be substituted for them in investigations of serotonergic cellular biology. In contrast to PF cells, MTC cells can be propagated in vitro to provide adequate amounts of material for blochemical studies. MTC cells were found to contain neuropeptides, including calcitonin, calcitonin gene-related peptide, and somatostatin, which have also been reported to be present in PF cells and enteric neurons. MTC cells also were observed to store endogenous 5-HT, to be able to synthesize ${ }^{3} \mathrm{H}-5-\mathrm{HT}$ from ${ }^{3} \mathrm{H}-\mathrm{L}-$ tryptophan, and to take up ${ }^{3} \mathrm{H}-5-\mathrm{HT}$ from the ambient medium by a carrier-mediated mechanism very similar to that of serotonergic neurons. In addition, the longterm accumulation of ${ }^{3} \mathrm{H}-5-\mathrm{HT}$ in MTC cells was antagonized by reserpine, suggesting that the cells contain $5-\mathrm{HT}$ storage vesicles that, like the synaptic vesicles of serotonergic neurons, are characterized by a reserpine-sensitive transporter of biogenic amines. MTC cells also contain type A, but not type B, monoamine oxidase. Finally, MTC cells were found to contain both 45 and $56 \mathrm{kDa}$ SBP. MTC cells thus retain a great many of the properties of PF cells, and, like PF cells, they are serotonergic cells with characteristics similar to

\footnotetext{
Received May 27, 1988; revised Aug. 30, 1988; accepted Sept. 5, 1988.

We wish to express our gratitude to Dr. S. S. Leong, Roswell Park Memorial Institute, Buffalo, NY, for her generous gift of the MTC cells; to Dr. Moses Chao Department of Cell Biology, Cornell University Medical College, New York, for donating the cell lines and the antibodies used for localizing the human NGF receptor; to Dr. A. Towle, Laboratory of Molecular Neurobiology, Cornell University Medical College, New York, for the antiserum to 5-HT; and to Dr. John Pintar, Columbia University College of Physicians and Surgeons, New York, for the antisera to MAO-A and MAO-B. This study was supported by NIMH Grant 37575 and AM 19743 .

Correspondence should be addressed to Hadassah Tamir, Division of Neuroscience, New York State Psychiatric Institute, 722 West 168th Street, New York, NY 10032.

Copyright (C) 1989 Society for Neuroscience $0270-6474 / 89 / 041199-14 \$ 02.00 / 0$
}

serotonergic neurons. Substantial differences were found in the content of immunoreactive 5-HT and neuropeptides in individual MTC cells. Moreover, the release of newly synthesized 5-HT to the medium exceeded the ability of the cells to store the amine. Studies of the ultrastructure of the MTC cells revealed a limited and highly variable number of secretory granules, probably accounting for their limited 5-HT storage capacity and for the heterogeneity of immunostaining with antisera to 5-HT or neuropeptides. In contrast to PF cells, MTC cells did not extend neurites in response to NGF, and NGF receptors could not be demonstrated immunocytochemically on MTC cells under conditions in which these receptors were readily visualized on other cells known to express them. Nevertheless, the MTC cells did appear to be capable of at least partially expressing a neural phenotype when the cells were grown in an impoverished medium. When this was done, the cells extended neuritic processes and expressed neurofilament immunoreactivity. Moreover, exposure of MTC cells to derivatives of CAMP (8-bromoCAMP and dibutyryl CAMP), especially in the presence of prostaglandin $E_{1}$, stimulated the expression of serotonergic properties. The ability of MTC cells to express neural characteristics and their expression of neuropeptides and 5-HT, which are also found in enteric neurons, indicate that MTC cells are suitable models for the study of serotonergic mechanisms. The data are also consistent with the hypothesis that PF cells and enteric neurons develop from a common neural crest-derived precursor cell that expresses an endocrine or a neuronal phenotype in different embryonic microenvironments.

The parenchyma of the thyroid gland is comprised of follicular and parafollicular (PF) cells. Because of their resemblance to neurons PF cells have been called paraneurons (Fujita, 1977). Follicular cells are derived embryologically from the pharyngeal endoderm, while PF cells are the descendents of precursors that migrate to the thyroid from the neural crest (Pearse, 1966; Bussolati and Pearse, 1967; Le Douarin and Teillet, 1974; Polak et a1., 1974; Fontaine, 1979). In this origin, PF cells are related to certain other endocrine cells, such as the chromaffin cells of the adrenal medulla (Le Douarin and Teillet, 1974) and the glomus cells of the carotid body (Pearse et al., 1973). The axial level of the neural crest from which the precursors of PF cells are derived has been shown in avian embryos to be the rhombencephalic or "vagal" region (corresponding to somites $1-7$ ). This is the 
same axial level of the crest that provides the cells that colonize the bowel and give rise to the enteric nervous system (Le Douarin, 1982). The common origin is of interest because, in addition to the peptide hormone, calcitonin (Pearse, 1966; Bussolati and Pearse, 1967), PF cells in many species contain neuroactive substances that are also found in enteric neurons. For example, 5-hydroxytryptamine (5-HT) is co-expressed with calcitonin in the PF cells of several mammals (Falck et al., 1964; Jaim-Etcheverry and Zeiher, 1968; Gershon and Nunez, 1970; Nunez and Gershon, 1972; Machado, 1976) and is an enteric neurotransmitter (Gershon et al., 1983; Costa et al., 1987). Other substances found in enteric neurons as well as PF cells include somatostatin (Kameda et al., 1985; Nunez et al., 1988) and calcitonin gene-related peptide (CGRP) (Tschopp et al., 1984). In sheep, PF cells have been demonstrated to store calcitonin and 5-HT within the same secretory vesicles (Barasch et al., 1987b). Moreover, although they have an endocrine phenotype, PF cells retain a neural potential. When sheep PF cells are separated from the thyroid, purified chromatographically, and exposed to $\beta$-nerve growth factor ( $\beta$-NGF) in vitro, the cells extend neurites (Barasch et al., 1987a). Once the neuritic branches have appeared, the cultured $\mathrm{PF}$ cells do not survive for more than 24-48 hr unless they are cocultured with aneuronal segments of gut. PF cclls with a ncural phenotype then survive indefinitcly in culture and decrease their expression of the endocrine hormone, calcitonin, while they increase expression of the neuropeptide, CGRP. PF cells, therefore, share a common origin in the neural crest with enteric neurons, contain several substances that are also found in enteric neurons, can assume a neural phenotype and, like enteric neural precursors, become responsive to an enteric microenvironment. It is possible that there is a common neural crest-derived stem cell that acquires an endocrine phenotype when it develops in the thyroid or a neuronal phenotype when it reaches the gut (Barasch et al., 1987a).

The relationship of PF cells to enteric neurons and their serotonergic properties make the PF cells a valuable model for the study of 5-HT-related mechanisms that are difficult to investigate in serotonergic neurons themselves. An organelle of serotonergic neurons the direct study of which has proven to be formidable is the 5-HT-containing synaptic vesicle. These vesicles have not been easy to isolate. Serotonergic neurons in both the periphery and CNS cannot be separated from other types of neuron; therefore, preparations of synaptic vesicles contain mixtures of vesicles containing several neurotransmitters in addition to 5-HT (Slotkin et al., 1978). On the other hand, PF cells can be separated from other cells of the thyroid gland and purified (Bernd et al., 1981). Furthermore, the secretory granules of PF cells (analogous to the synaptic vesicles of neurons) can be isolated and their properties determined (Barasch et al., 1987b). A great deal has been learned about subcellular organelles that store catecholamines from the investigation of the properties of adrenal medullary chromaffin granules (Johnson, 1988). In an analogous manner, considerable progress may be made in discerning the nature of serotonergic storage organelles by examining the secretory granules of PF cells.

Like central and enteric serotonergic neurons, PF cells are capable of synthesizing 5-HT and transporting the newly synthesized 5-HT into the secretory granules (Nunez and Gershon, 1972). In addition, as in serotonergic neurons (Tamir et al., 1976; Jonakait et al., 1977, 1979; Tamir and Gershon, 1979), PF cells store 5-HT in storage organelles together with a specific 5-HT binding protein (SBP) (Bernd et al., 1979, 1981; Barasch et al., 1987a, b). SBP has been purificd, and 2 forms of the protein have been found, with apparent molecular weights of 45 and $56 \mathrm{kDa}$ (Gershon et al., 1983; Liu et al., 1985). Studies of the rat brain have indicated that $45 \mathrm{kDa}$ SBP is enriched in axon terminals, whereas $56 \mathrm{kDa} \mathrm{SBP}$ is more concentrated in the perikarya and preterminal axons of serotonergic neurons (Gershon et al., 1983), and it has been suggested that $56 \mathrm{kDa}$ SBP may be the precursor of $45 \mathrm{kDa}$ SBP (Liu et al., 1985). These observations, while not conclusive, imply that $45 \mathrm{kDa}$ SBP may be the mature form of a 5-HT storage protein that is a component of synaptic vesicles. Supporting this hypothesis is the observation that it is $45 \mathrm{kDa}$ SBP that is costored with 5-HT in the secretory granules of PF cells (Barasch et al., 1987b). In the rat brain, immunocytochemical studies have shown that both 45 and $56 \mathrm{kDa}$ SBP are co-expressed with 5 -HT in the same neurons (Kirchgessner et al., 1988). Neither 45,kDa nor $56 \mathrm{kDa}$ SBP is present in cells that store $5-\mathrm{HT}$ but are not derived from the neurectoderm, such as platelets, mast cells, and enterochromaffin cells (Gershon and Tamir, 1984).

One drawback of PF cells as an investigative model is that it is difficult to obtain enough material from slaughtered sheep to use for biochemical analyses. These analyses would be facilitated if experiments could be performed on an ample supply of readily available cells. We have therefore undertaken to characterize a human medullary thyroid carcinoma (MTC) cell line. This cell line (also called TT), first isolated by Leong et al. (1981), is derived from a carcinoma of PF cells. The MTC cells were compared to PF cells in their ability to extend neurites, their synthesis, storage and uptake of 5-HT, the presence of 45 and $56 \mathrm{kDa}$ SBP, and their co-expression of neuropeptides and calcitonin. Although some significant differences were discovered between PF cells and MTC cells, the MTC cell line was found to retain many neural and serotonergic characteristics and to represent a useful model, relevant to neurons, for the study of the role of SBP in 5-HT storage organelles.

\section{Materials and Methods}

Cell culture. MTC cells were grown in $20 \times 100 \mathrm{~mm}$ Corning polystyrene tissue culture dishes at $\left(1 \times 10^{6}\right.$ cells/dish $)$ or in $75 \mathrm{~cm}^{2}$ Corning polystyrene flasks $\left(2 \times 10^{6} \mathrm{cells} /\right.$ flask $)$. For immunocytochemical studies, the cells were grown on glass coverslips (Corning, NY). The cells were grown, unless otherwise stated, in RPMI medium 1640 supplemented with 2 mM L-glutamine, 100 units penicillin, $100 \mu \mathrm{g}$ streptomycin/Inl, and either $15 \%$ fetal bovine serum (FBS) or $1 \%$ horse serum (HS), all purchased from GIBCO Laboratories (Grand Island, NY). Cells were grown at $37^{\circ} \mathrm{C}$ in a humidified atmosphere containing $5 \% \mathrm{CO}_{2}$. In some experiments, the glass coverslips were coated with various adhesive substrates. These substrates included laminin (Collaborative Research Inc. Bedford, MA), reconstituted basal lamina material (Matrigel; Collaborative Research), or rat tail collagen polymerized with ammonia vapor. Laminin $(2 \mu \mathrm{g} / \mathrm{ml})$ was added to sterilized coverslips for $5 \mathrm{hr}$ and rinsed off with medium. Matrigel was spread over coverslips at $4^{\circ} \mathrm{C}$ and polymerized at $37^{\circ} \mathrm{C}$ for $30 \mathrm{~min}$. In other experiments, the cells were treated with either the $\beta$ subunit of nerve growth factor $(\beta-N G F ; 50 \mathrm{ng} / \mathrm{ml}$; Collaborative Research), phorbol 12 -myristate-13-acetate (1 $\mu \mathrm{M}$; Sigma Chemical, St. Louis, MO), or several derivatives of cyclic AMP (1 mM). The cyclic derivatives were 8-bromoadenosine $3^{\prime}: 5^{\prime}$-cyclic monophosphate (8-bromo-cAMP; Sigma), 8-(4-chlorophenylthio)adenosine 3', $5^{\prime}$-cyclic monophosphate (8-chlorophenyl cAMP; Sigma), and $\mathrm{N}^{6}-2^{\prime}-O$ dibutyryladenosine 3', 5'-cyclic monophosphate (dibutyryl cAMP; Sigma). At various time points in the growth cycle (usually 1-2 weeks), the cells were removed from the flasks with trypsin $0.05 \%$ and EDTA $0.02 \%$ (GIBCO) and, after inactivation of the trypsin with serum, were washed twice with PBS. The cells were centrifuged and stored as a pellet at $-20^{\circ} \mathrm{C}$ until analyzed.

Immunocytochemistry. Cells were fixed with $4 \%$ formaldehyde (freshly prepared from paraformaldehyde) in $0.1 \mathrm{~m}$ PBS ( $\mathrm{pH}$ 7.4) for $10 \mathrm{~min}$ 
at room temperature. Cells were permeabilized with $0.2 \%$ Triton-X 100 (Sigma) in 0.1 M PBS for $5 \mathrm{~min}$ before application of one of the several primary antibodies. Primary antibodies included (1) partially purified rabbit polyclonal antisera to 45 and $56 \mathrm{kDa}$ SBP (1:200; Kirchgessner et al., 1988), (2) a rabbit polyclonal antiserum to 5 -HT (prepared by Dr. A. Towle, Cornell University Medical College) purified on an affinity column as described below, (3) rabbit antiserum to human calcitonin (1:400; Immunonuclear Corp., Stillwater, MN; Nunez et al., 1988), (4) rabbit antiserum to human CGRP (1:2000; Peninsular Labs, Belmont, CA; Nunez et al., 1988), (5) a rabbit antiserum to substance P (Accurate Chemical \& Scientific Corp., Westbury, NY; Nunez et al., 1988), (6) sheep antisera to MAO-A and to MAO-B (1:500; kindly supplicd by Dr. J. Pintar, Department of Anatomy and Cell Biology, College of Physicians and Surgeons of Columbia University, NY), (7) rabbit antiserum to somatostatin (1:200; Accurate), (8) a mouse monoclonal antibody recognizing the nonphosphorylated forms of the $150 \mathrm{kDa}(\mathrm{M})$ and $200 \mathrm{kDa}(\mathrm{H})$ neurofilament proteins $(1: 150$; Sternberger and Meyer Immunocytochemicals Inc., Jarretsville, MD; Payette et al., 1985), and (9) a mouse monoclonal antibody to the human NGF receptor (undiluted; kindly supplied by Dr. M. Chao, Department of Cell Biology, Cornell University Medical School, NY). Primary antisera were diluted with $0.1 \mathrm{M}$ PBS and applied for $2 \mathrm{hr}$ at room temperature. The various rabbit antisera were localized with goat anti-rabbit IgG $(1: 200$; Kirkegaard and Perry, Gaithersburg, MD) coupled to rabbit HRP (1:400; Jackson ImmunoResearch Labs Inc., Avondale, PA). HRP was then visualized with $3,3^{\prime}$-diaminobenzidine and $\mathrm{H}_{2} \mathrm{O}_{2}, \mathrm{H}_{2} \mathrm{O}_{2}$ was generated with a glucose/glucose oxidase system (Itoh et al., 1979). Mouse primary antibodies were localized, unless otherwise stated, with biotinylated rabbit anti-mouse IgG (1:400; Kirkegaard and Perry) and visualized with avidin coupled to enteric mucosal alkaline phosphatase (alkaline phosphatase substrate kit III; Vector Labs Inc., Gaithersburg, MD) to give a blue reaction product. The staining was performed in the presence of $1 \mathrm{~mm}$ levamisole (Sigma) to inhibit endogenous (nonenteric mucosal) alkaline phosphatase (Ponder and Wilkinson, 1981). Sheep antisera were localized using biotinylated rabbit anti-sheep IgG (1:400; Kirkegaard and Perry) and were visualized with avidin-alkaline phosphatase (1: 400; Vector Labs). Control experiments consisted of incubating tissue with nonimmune sera and omitting the primary antiserum.

Purification of antisera to 5-HT. The crude antiserum was purified by affinity chromatography on a $\beta$-carboline Sepharose column. In order to prepare the affinity column, 5-HT was first coupled to BSA according to the method of Steinbusch et al. (1978). The product, BSA- $\beta$-carboline (20 mg), was then bound to $\mathrm{CNBr}$ activated Sepharose 4-B (1 gm) according to the method of Cuatrecasas et al. (1968). The anti-5-HT serum $(0.5 \mathrm{ml})$ was applied to the affinity column $(0.6 \times 6 \mathrm{~cm})$ after its equilibration with $20 \mathrm{~mm}$ potassium phosphate buffer $(\mathrm{pH} 7.4)$. The column was washed with the same buffer, and the antibody was eluted with acetic acid (1.0 $\mathrm{m} ; \mathrm{pH} 2.8)$. The eluted fraction was immediately neutralized with solid Tris base.

Assay of 5-HT. Pelleted cells were acidified, unless otherwise stated, with 0.1 M $\mathrm{HClO}_{4}$, homogenized with a Polytron (Brinkmann Instruments, Westbury, NY) and centrifuged for $5 \mathrm{~min}$ at $15,000 \times \mathrm{g}$. Aliquots of the clear supernatant were analyzed by reverse-phase high-pressure liquid chromatography (HPLC) using electrochemical detection. The HPLC system consisted of a Waters Associates (Milford, MA) model $6000 \mathrm{~A}$ delivery system, a U6K injector, a $\mathrm{C} 18$ reverse-phase column (Zurbax ODS, $25 \mathrm{~cm} \times 4.6 \mathrm{~mm}$; DuPont Co., Wilmington, DE), a Bioanalytical Systems (West Lafayette, IN) LC-4A amperometric detector coupled to a TL-5 glassy carbon electrode and a Waters data module (M730) for integrating, recording, and printing the data. The electrochemical detector was set at a potential of $0.7 \mathrm{~V}$. Unless otherwise stated, the solvent system was the one described by Reinhard et al. (1980).

Determination of the uptake and accumulation of ${ }^{3} \mathrm{H}-5-\mathrm{HT}$. Suspended cells $\left(2 \times 10^{6}\right.$; in RPMI 1640) were incubated for 5 or $20 \mathrm{~min}$ with ${ }^{3} \mathrm{H}-5-\mathrm{HT}(0.5 \mu \mathrm{M})$ in the presence or absence of zimelidine $(1 \mu \mathrm{M}$; Astra-Lakemedl, Sweden) or fluoxetine ( $1 \mu \mathrm{M}$; Eli Lilly, Indianapolis, IN) at $37^{\circ} \mathrm{C}$. The effect of reserpine $(2 \mu \mathrm{M})$ on the ability of MTC cells to accumulate ${ }^{3} \mathrm{H}-5$-HT was tested by preincubating the cells in serumfree medium for $2 \mathrm{hr}$ before adding ${ }^{3} \mathrm{H}-5-\mathrm{HT}$ and prolonging the time of incubation to $1 \mathrm{hr}$. In control experiments, the incubation with ${ }^{3} \mathrm{H}$ 5 -HT was carried out at $4^{\circ} \mathrm{C}$. The reaction was stopped by chilling the tubes and centrifuging $(10,000 \times \mathrm{g}, 5 \mathrm{~min})$. The pellet was washed twice with PBS and homogenized with a Polytron $(x)$ in the presence of $0.1 \mathrm{M}$ $\mathrm{HClO}_{4}$, centrifuged $(10,000 \times g, 5 \mathrm{~min})$, and the supernatant was subjected to liquid scintillation spectrometry.
Activity of tryptophan hydroxylase (EC 1.14.16.4). Cells were growI for this experiment in NUserum(x) supplemented with insulin, transferrin, selenium, and linoleic acid (ITS $\odot$ Premix; Collaborative Research). The activity of tryptophan hydroxylase was measured by following the conversion of ${ }^{3} \mathrm{H}$-L-tryptophan to ${ }^{3} \mathrm{H}-5$-HT. MTC cells $\left(2 \times 10^{6}\right)$ were washed and suspended in RPMI 1640 and incubated at $37^{\circ} \mathrm{C}$ for various time intervals in the presence of pargyline $\left(10^{-5} \mathrm{M}\right)$ and ${ }^{3} \mathrm{H}-\mathrm{L}$-tryptophan $(1.7 \mu \mathrm{M}, 50 \mathrm{Ci} / \mathrm{mmol}$; New England Nuclear, Dupont). Nonradioactive tryptophan was added to bring the final concentration of $\mathrm{I}$-tryptophan in the medium to $50 \mu \mathrm{M}$. The cells were harvested, washed twice with PBS, and homogenized in $\mathrm{HClO}_{4}(0.1 \mathrm{M})$. The homogenate was centrifuged $(15,000 \times g, 5 \mathrm{~min})$, and the concentrations of 5-HT and 5-HIAA in the supernatant were assayed by means of HPLC. The mobile phase used for HPLC in this experiment consisted of $0.1 \mathrm{M} \mathrm{NaH}_{2} \mathrm{PO}_{4}, 0.1 \mathrm{~mm}$ $\mathrm{Na}_{2}$ EDTA, and $6 \%$ methanol pH 3.0 (adjusted with phosphoric acid). This solvent system, at a flow rate of $1.1 \mathrm{ml} / \mathrm{min}$, allows the complete separation of 5-HT, tryptophan, and 5-HIAA (retention times: 6.0, 12.5, and $17.5 \mathrm{~min}$, respectively). The detector for this system was set at 0.6 $\mathrm{V}$ (Sah and Matsumoto, 1987). Fractions $(0.5 \mathrm{ml})$, corresponding to the areas under the peaks, were collected directly into scintillation vials, 5 $\mathrm{ml}$ liquid scintillation fluid (Ultrafluor) was added, and the fractions were subjected to liquid scintillation spectrometry (Beckman RC 9000).

Activity of $M A O$. MAO activity was measured in crude mitochondrial pellets by the method of Shie and Eiduson (1973) as previously described (Liu et al., 1987). In brief, the fraction $(750 \mu \mathrm{g}$ ) was incubated with 5 -HT $(0.1 \mathrm{~mm})$ as substrate for $30 \mathrm{~min}$ at $37^{\circ} \mathrm{C}$. The reaction was terminated with $\mathrm{HClO}_{4}(0.1 \mathrm{M})$, and, after centrifugation, the supernatant was injected directly into an HPLC column for determination of 5-HIAA. For inhibition studies, the fraction was either preincubated with $1 \mu \mathrm{M}$ clorgyline (Johnston, 1968; Neff and Yang, 1974) or $1 \mu \mathrm{M}$ deprenyl (Knoll and Magyar, 1972) prior to the addition of substrate.

Preparation and partial purification of $S B P$. The pellet of the frozen cells was dispersed in $0.02 \mathrm{M}$ potassium phosphate buffer $(\mathrm{pH} 7.5)$ containing $1 \mathrm{~mm}$ EGTA and protease inhibitors $(0.1 \mathrm{mg} / \mathrm{ml}$ leupeptin, $0.1 \mathrm{mg} / \mathrm{ml}$ pepstatin, and $0.5 \mathrm{~mm}$ PMSF), disrupted with a Polytron(사, and centrifuged at $100,000 \times g$ for $60 \mathrm{~min}$. The supernatant was fractionated with ammonium sulfate, $0-30 \%$ saturation. The precipitated protein was suspended in potassium phosphate buffer $(0.02 \mathrm{M}, \mathrm{pH} 7.5)$ and used for analyzing the ability to bind ${ }^{3} \mathrm{H}-5-\mathrm{HT}$ after dialysis for 3 hr against the same buffer.

Assay of ${ }^{3} H-5-H T$ binding to $M T C$ cell proteins. The assay for binding of ${ }^{3} \mathrm{H}-5$-HT by partially purified proteins has been described previously (Tamir, 1982). Briefly, the protein $(25 \mu \mathrm{g})$ was incubated with ${ }^{3} \mathrm{H}-5-\mathrm{IIT}$ $(0.2 \mu \mathrm{M})$ and $\mathrm{Fe}^{2+}(0.1 \mathrm{mM})$. Unless otherwise stated, the incubation was carried out in potassium phosphate buffer $(20 \mathrm{~mm}, \mathrm{pH}$ 7.4). The resulting protein- $\mathrm{Fe}^{2+}-{ }^{3} \mathrm{H}-5-\mathrm{HT}$ complex was then separated from free ${ }^{3} \mathrm{H}-5-\mathrm{HT}$ on a Sephadex G-50 column $(1 \times 10 \mathrm{~cm})$. Nonspecific binding, measured in the presence of a 1000 -fold excess of nonradioactive $5-\mathrm{HT}$, was subtracted from the total amount of the ${ }^{3} \mathrm{H}-5-\mathrm{HT}$ bound to SBP. In experiments in which the effect of inhibitors was tested, the potential inhibitor was added just before ${ }^{3} \mathrm{H}-5-\mathrm{HT}$. Preparation of the protein-Fe ${ }^{2+}-{ }^{3} \mathrm{H}-5-\mathrm{HT}$ complex for SDS-PAGE was carried out according to Liu et al. (1987).

\section{Results}

\section{Morphology and peptide immunoreactivity of $M T C$ cells} grown with $F B S$

When MTC cells were grown in RPMI media supplemented with $15 \%$ FBS, the population doubling time was approximately $80 \mathrm{hr}$. This is similar to the time found by Leong et al. (1981). Cells grown under these conditions (Fig. 1A) were round to fusiform in contour ( $\sim 45 \mu \mathrm{m}$ in longest diameter) and had occasional short processes that rarely exceeded 1-2 cell diameters in length; the cultures reached a high cell density $\left(\sim 1 \times 10^{6}\right.$ cells $\left./ \mathrm{cm}^{2}\right)$. Cells grew well on both plastic and glass. Coating glass coverslips with either rat tail collagen or reconstituted basal laminae (Matrigel) did not affect morphology or doubling time; however, cells grown on laminin formed clumps instead of uniform monolayers. Doubling time was about the same on laminin as on other substrates. When grown with FBS on glass or plastic, the MTC cells expressed calcitonin (Fig. 1B), CGRP (Fig. 1C), and somatostatin (Fig. 1D) immunoreactivities. The immuno- 

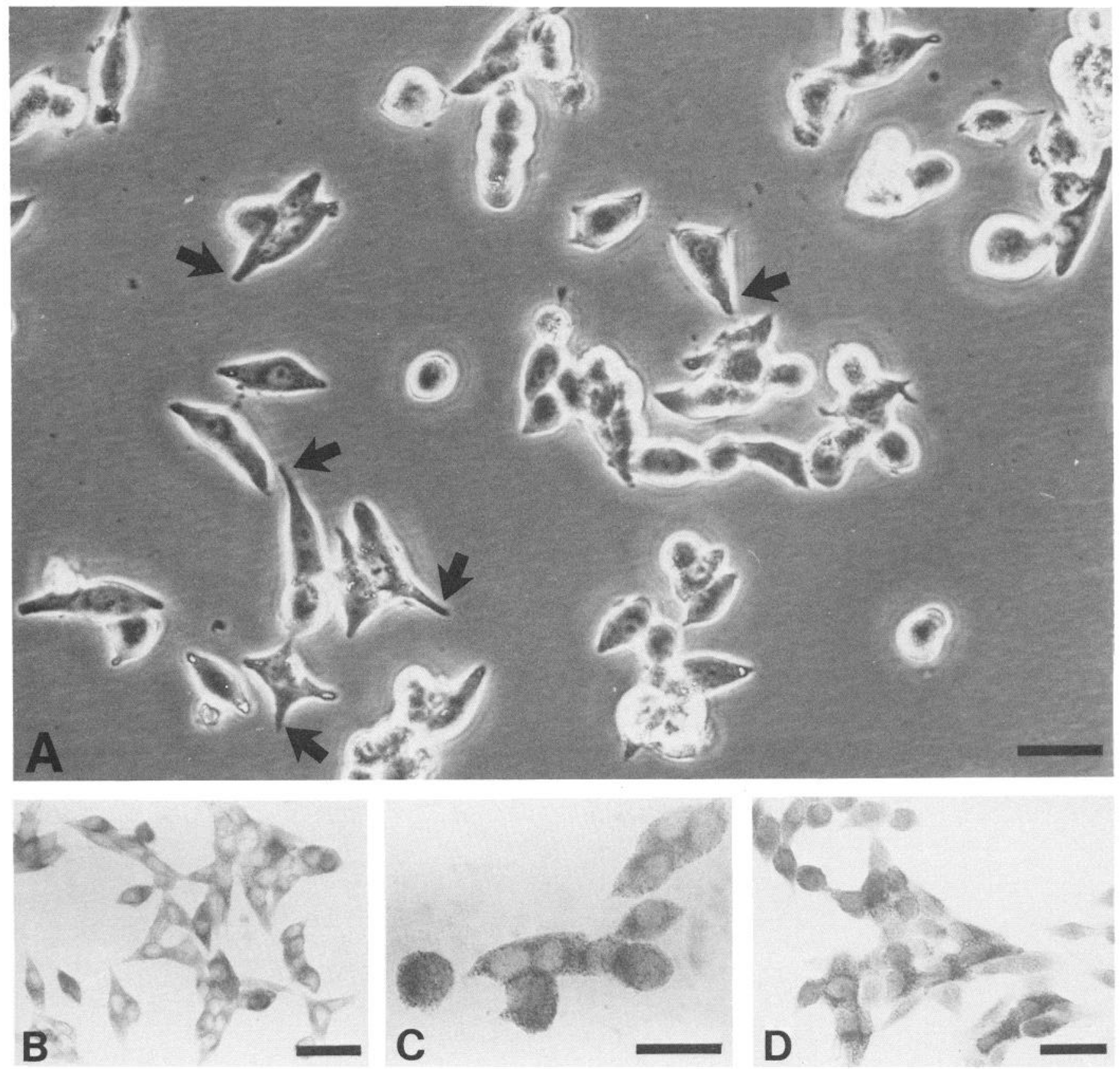

Figure 1. Micrographs showing cultures of MTC cells grown in enriched medium (containing $15 \%$ FBS). A, When visualized by phase-contrast microscopy the MTC cells are rounded, fusiform, or polyhedral in contour. Some cells have short processes $(\rightarrow)$; however, these processes are not longer than 1 cell diameter. $B$, Calcitonin immunoreactivity in MTC cells. $C$, CGRP immunoreactivity. $D$, Somatostatin immunoreactivity. A similar granular pattern of cytoplasmic immunostaining is found with antisera to each of the 3 neuropeptides. Scale bars $(A-D), 30 \mu \mathrm{m}$.

reactivity of each of these neuropeptides was restricted to the cytoplasm and had a granular appearance. There was marked variation between cells in the same culture dish in the intensity of their immunostaining; some cells were highly immunoreactive, while others appeared to be only lightly stained. For example, when CGRP immunoreactivity was demonstrated, $89 \%$ ( $n=200)$ of the cells were intensely immunostained and $11 \%$ of the cells showed moderate immunoreactivity; the equivalent numbers for somatostatin-immunoreactive cells were $31 \%(n=$ 215 ) intensely immunoreactive and $60 \%$ moderately immunoreactive. This difference is significant $(p<0.001)$. Substance $\mathrm{P}$ immunoreactivity was not detected in the MTC cells.

\section{Serotonergic properties of MTC cells grown with FBS}

If MTC cells are to be useful as a model system relevant to serotonergic neurons, it is necessary to demonstrate that the cells express 5-HT-related properties similar to those expressed by serotonergic neurons. Accordingly, a number of 5-HT-related markers were screened to determine the degree of similarity between MTC cells and serotonergic neurons. The markers that were examined included the presence of stores of endogenous 5-HT, the capacity to synthesize ${ }^{3} \mathrm{H}-5-\mathrm{HT}$ from ${ }^{3} \mathrm{H}-\mathrm{L}-$ tryptophan, the existence of a specific uptake mechanism for ${ }^{3} \mathrm{H}-5$ HT, the ability to degrade $5-\mathrm{HT}$ by monoamine oxidase, and 


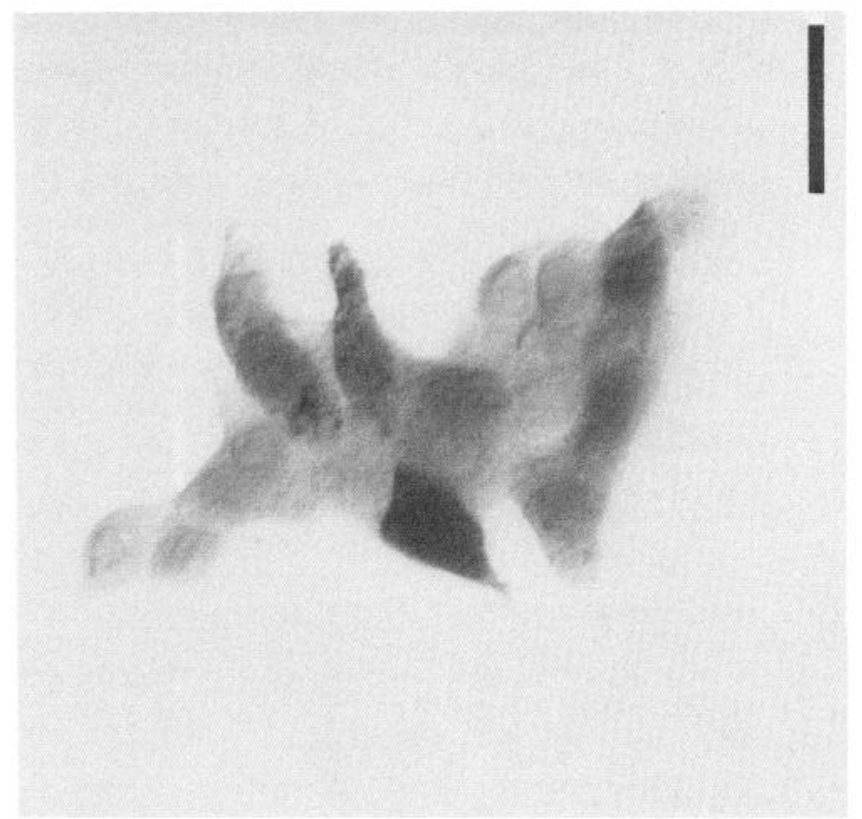

Figure 2. 5-HT immunoreactivity in a culture of MTC cells grown in enriched medium. There are marked differences in the intensity of immunostaining of individual MTC cells. Scale bar, $15 \mu \mathrm{m}$.

the presence of the specific 5-HT binding protein, SBP.

Total 5-HT. Immunocytochemical studies, using a monospecific antiserum to $5-\mathrm{HT}$, revealed the presence of $5-\mathrm{HT}$ immunoreactive material in $97 \%(n=200)$ of MTC cells. As was also true of peptides, the intensity of 5-HT immunostaining was highly variable between cells in the same culture dish; $67.5 \%$ of cells were intensely immunoreactive, $29.5 \%$ were moderately immunoreactive, and $3 \%$ were unstained. Within the cells, 5-HT immunoreactivity was cytoplasmic and granular, although a lighter diffuse immunoreactivity was also seen throughout the cytoplasm (Fig. 2). Levels of 5-HT could also be demonstrated and quantitatively determined by HPLC with electrochemical detection. The 5-HT level of MTC cells was found to be $1.96 \pm 0.66 \mathrm{fg} /$ cell $(n=6$ cultures). Assuming the MTC cells are spherical in shape, their approximate volume, estimated from the mean cell diameter, is $\sim 4 \mathrm{pl}$. From this figure and the per cell content of 5-HT, the approximate intracellular concentration of 5-HT, averaged over all of the cells grown in FBS, can be estimated to be about $3 \mu \mathrm{M}$. Not all cells that contain 5-HT are able to synthesize the amine. Platelets and sympathetic nerves in the pineal gland, for example, both contain high concentrations of 5-HT acquired by uptake from the medium (Gershon, 1977). Serotonergic neurons, on the other hand, contain tryptophan hydroxylase and are capable of 5-HT biosynthesis. The 5-HT content of MTC cells was therefore determined for cells grown in $10 \%$ NUserum $\otimes$, which contains very little 5-HT (examined by HPLC and found to be $<20$ $\mathrm{pmol} / \mathrm{ml}$ ). MTC cells grown in NUserum $@$ were immunostained by anti-5-HT sera; however, the proportion of unstained cells significantly increased over that seen in cells grown in FBS; $63 \%$ of cells $(n=200)$ were intensely immunoreactive, $27 \%$ were moderately immunoreactive, and $10 \%$ were unstained $(p<0.02)$. Moreover, the level of 5-HT was also lower in cells grown in NUserum $\times(0.4 \pm 0.05 \mathrm{fg} /$ cell; $n=10$ cultures $)$ than in MTC cells grown in FBS $(p<0.05)$.

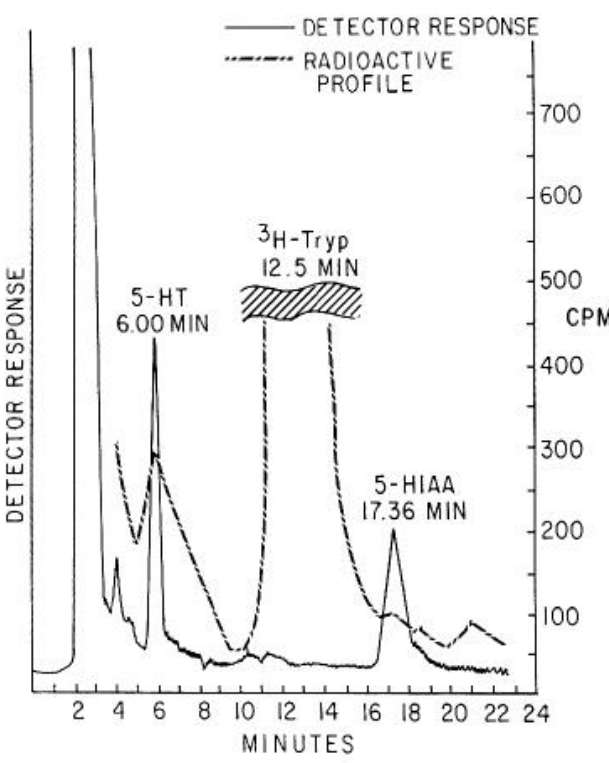

Figure 3. Biosynthesis of ${ }^{3} \mathrm{H}-5-\mathrm{HT}$ from ${ }^{3} \mathrm{H}-\mathrm{L}-$ tryptophan by MTC cells was studied by HPLC with electrochemical detection. A typical chromatogram is illustrated. The solid line shows the response of the detector to added standards, while the broken line depicts the peaks of eluted radioactivity. Note the clear separation of 5-HT, ${ }^{3} \mathrm{H}-\mathrm{L}$-tryptophan, and 5-HIAA. An electrochemical signal is not obtained from tryptophan; however, its retention time is evaluated by applying ${ }^{3} \mathrm{H}-\mathrm{L}-$ tryptophan and counting the effluent from the HPLC column.

Synthesis of ${ }^{3} \mathrm{H}-5-\mathrm{HT}$ from ${ }^{3} \mathrm{H}$-L-tryptophan. The ability of MTC cells to synthesize ${ }^{3} \mathrm{H}-5$-HT from ${ }^{3} \mathrm{H}-\mathrm{L}$-tryptophan was tested in order to determine whether they contain tryptophan hydroxylase as do serotonergic neurons. It has already been demonstrated that MTC cells are rich in aromatic $\mathrm{L}$-amino acid decarboxylase (Baylin and Mendelssohn, 1980). For these experiments, cells were grown in NUserum $\times$ in order to eliminate the possibility that accumulated exogenous 5 - $\mathrm{HT}$ might downregulate its biosynthetic enzymes. Cells were incubated with ${ }^{3} \mathrm{H}$ L-tryptophan for 1, 2, and $4 \mathrm{hr}$ in the presence of pargyline (10.0 $\mu_{\mathrm{M})}$ prior to harvesting. Control injections of the incubation medium containing ${ }^{3} \mathrm{H}$-tryptophan confirmed that the media contained no ${ }^{3} \mathrm{H}-5$-HT or ${ }^{3} \mathrm{H}-5$-hydroxytryptophan in the absence of added cells. When the radioactive reaction products and reactants were separated by HPLC (Fig. 3) and counted, a consistent conversion of ${ }^{3} \mathrm{H}$-L-tryptophan to ${ }^{3} \mathrm{H}-5$-HT was observed. No continued metabolism of ${ }^{3} \mathrm{H}-5-\mathrm{HT}$ appeared to occur; if ${ }^{3} \mathrm{H}$-5-HIAA was present, its concentration was below the level of detectability, which was $0.03 \mathrm{fg} /$ cell ( $n=5$ cultures). Extraction of radioactive material from MTC cells grown in NUserum $\times$ revealed that they synthesized and retained $0.5 \pm$ $0.3 \mathrm{fg}{ }^{3} \mathrm{H}-5-\mathrm{HT} / \mathrm{cell} / \mathrm{hr}$ ( $n=4$ cultures). Prolonging the incubation time to $4 \mathrm{hr}$ did not increase the net synthesis of retained ${ }^{3} \mathrm{H}-5-\mathrm{HT}$. The failure of newly synthesized ${ }^{3} \mathrm{H}-5-\mathrm{HT}$ to accumulate in MTC cells as a function of time suggested that the cells might release ${ }^{3} \mathrm{H}-5$-HT soon after its biosynthesis. We therefore tested the hypothesis that newly synthesized ${ }^{3} \mathrm{H}-5-\mathrm{HT}$ is released by measuring the amount of ${ }^{3} \mathrm{H}-5$ - $\mathrm{HT}$ in the growth medium following incubation with ${ }^{3} \mathrm{H}$-L-tryptophan. The medium accumulated ${ }^{3} \mathrm{H}-5$-HT at the rate of $2.8 \pm 2 \mathrm{fg} / \mathrm{cell} / \mathrm{hr}(n$ $=4$ cultures). Since ${ }^{3} \mathrm{H}-5$-HT appeared in the medium to a greater extent and at a faster rate than in the MTC cells themselves, it was concluded that MTC cells rapidly release newly synthesized 5-HT. 
Uptake of ${ }^{\prime} H-5-H T$. The uptake of ${ }^{3} \mathrm{H}-5-\mathrm{HT}$ by MTC cclis (grown in medium supplemented with FBS) was examined in the presence and absence of specific inhibitors of the neural uptake of 5-HT. The uptake inhibitors that were used, fluoxetine or zimelidine, are potent antagonists of uptake of 5-HT by both central and peripheral serotonergic neurons and have relatively little effect on the uptake of catecholamines by central or peripheral noradrenergic neurons (Jonakait et al., 1979; Ross, 1982). Uptake of ${ }^{3} \mathrm{H}-5-\mathrm{HT}$ was found to be linear as a function of time for $20 \mathrm{~min}$. MTC cells accumulated ${ }^{3} \mathrm{H}-5-\mathrm{HT}$ to the extent of $0.39 \pm 0.03 \mathrm{fg} / \mathrm{cell} / \mathrm{min}$ ( $n=5$ cultures) (Fig. 4). The uptake of ${ }^{3} \mathrm{H}-5-\mathrm{HT}$ was inhibited by fluoxetine $(70+10 \%$ inhibition at $1.0 \mu \mathrm{M} ; p<0.01$ vs control; Fig. 4$)$ and by zimelidine $(60 \pm$ $13 \%$ inhibition at $1.0 \mu \mathrm{M} ; p<0.01$ vs control; Fig. 4). The uptake of ${ }^{3} \mathrm{H}-5-\mathrm{HT}$ was temperature dependent since the amount of ${ }^{3} \mathrm{H}-5$-HT taken up by the cells was decreased by $90 \pm 9 \%(p$ $<0.001$; Fig. 4) at $4^{\circ} \mathrm{C}$. The uptake of ${ }^{3} \mathrm{H}-5-\mathrm{HT}$ was diminished by $50 \pm 6 \%(p<0.002)$ when the temperature was decreased by $10^{\circ} \mathrm{C}$, indicating that the $Q_{10\left(27^{\circ}-37^{\circ}\right)}$ is 2 . This $Q_{10}$ and the effect of specific inhibitors on the accumulation of ${ }^{3} \mathrm{H}-5-\mathrm{HT}$ indicate that the uptake of ${ }^{3} \mathrm{H}-5-\mathrm{HT}$ by MTC cells is carrier-mediated.

The effect of reserpine on the accumulation of ${ }^{3} \mathrm{H}-5-\mathrm{HT}$ was determined in order to evaluate the ability of MTC cells to store 5-HT in subcellular vesicles. Reserpine is known not to affect the transmembrane transport of 5-HT by serotonergic neurons; however, reserpine is known to inhibit the concentration of intracellular biogenic amines, including 5-HT, in synaptic vesicles (Carlsson, 1965). In the presence of reserpine $(2 \mu \mathrm{M})$, the initial uptake of ${ }^{3} \mathrm{H}-5-\mathrm{HT}$ from the medium was not significantly altered (no change from control in the uptake of ${ }^{3} \mathrm{H}-5-\mathrm{HT}$ in 5 min; $n=5$ cultures). In contrast, the accumulation of ${ }^{3} \mathrm{H}-5-\mathrm{HT}$ in MTC cells over a $60 \mathrm{~min}$ period was inhibited by $65 \pm$ $10 \%$ ( $p<0.01 ; n=5$ cultures). The initial uptake of ${ }^{3} \mathrm{H}-5-\mathrm{HT}$ (uptake, as noted above, is linear for $20 \mathrm{~min}$ ) reflects the transmembrane transport of the amine, while its accumulation, measured at $60 \mathrm{~min}$, is a function not only of the 5-HT uptake mechanism but also of the ability of the cells to sequester ${ }^{3} \mathrm{H}$ 5-HT and thus prevent its catabolism or loss by back-diffusion. The effect of reserpine to antagonize the long-term accumulation of ${ }^{3} \mathrm{H}-5-\mathrm{HT}$ indicates that MTC cells have a reserpine-sensitive mechanism for sequestering 5-HT that is similar to that represented in serotonergic neurons by synaptic vesicles. The observations that MTC cells can take up and accumulate exogenous 5-HT indicate that levels of 5-HT measured in MTC cells cannot be considered to reflect stores of endogenously synthesized 5-HT unless the cells are grown in 5-HT-free medium. FBS contains 5-HT (Agrez et al., 1984); the FBS used in the current experiments was found by HPLC to contain $\sim 50 \mathrm{ng} /$ $\mathrm{ml}$ of 5-HT. The 5-HT content of MTC cells grown in the presence of FBS, therefore, probably includes both amine synthesized by the cells and 5-HT taken up from the medium.

$M A O$ activity. MAO type A-like immunoreactivity was found in MTC cells (Fig. 5A); however, that for MAO type B was not. Control cells incubated with preimmune sera were not stained (Fig. 5B). To test whether the immunoreactive MAO-A in MTC cells was catalytically active, MAO activity was assayed in a crude mitochondrial fraction prepared from MTC cells, using 5-HT as a substrate. MAO activity was found, the preparations producing $0.45 \pm 0.03 \mathrm{nmol} 5-\mathrm{HIAA} / \mathrm{mg}$ protein $/ \mathrm{hr}$. This activity was inhibited (by $>95 \% ; n=5$ cultures; $p<0.001$ ) by the specific MAO-A inhibitor clorgyline $(1 \mu \mathrm{M})$ but was not significantly inhibited by the specific MAO-B inhibitor deprenyl
Initlal Uptake of [ $\left.{ }^{5} \mathrm{H}\right] 5 \cdot \mathrm{HT}$ by MTC Cells

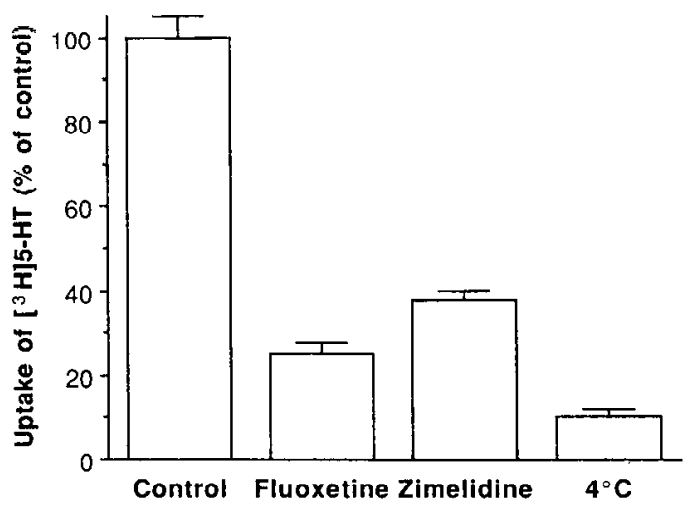

Figure 4. Initial uptake of ${ }^{3} \mathrm{H}-5-\mathrm{HT}$ by MTC cells (estimated at $5 \mathrm{~min}$, during the period when uptake is a linear function of time). Uptake is inhibited by fluoxetine, zimelidine, and incubation at $4^{\circ} \mathrm{C}$. The cells were from cultures grown in enriched medium

( $1 \mu \mathrm{M} ; n=5$ cultures). It is concluded that MAO-A is present and enzymatically active in MTC cells grown in the presence of FBS but that the cclls do not contain MAO-B.

Detection and characterization of SBP. Monospecific polyclonal antisera directed either against 45 or $56 \mathrm{kDa}$ SBP (Kirchgessner et al., 1988) immunostained MTC cells (Fig. 6, $A, C$ ). The immunoreactivity of $45 \mathrm{kDa} \mathrm{SBP}$ was more intense than that of $56 \mathrm{kDa}$ SBP. Neither MTC cells incubated in the presence of preimmune sera nor hippocampal neurons, which do not contain 5-HT or SBP (Kirchgessner et al., 1988), were immunostained (Fig. 6B). As was also seen when neuropeptides and 5-HT were demonstrated immunocytochemically, the intensity of SBP immunoreactivity varied greatly between cells in the same cultures. SBP immunoreactivity was limited to the cytoplasm of the MTC cells and appeared as a granular pattern superimposed on a diffusely immunoreactive background (Fig. 6A).

SBP activity was also studied in homogenates of MTC cells in order to help confirm that the immunoreactive matcrial was actually SBP. Protein in the high-speed supernatant fraction was partially purified with $\left(\mathrm{NH}_{4}\right)_{2} \mathrm{SO}_{4}(0-30 \%)$ and incubated with ${ }^{3} \mathrm{H}-5-\mathrm{HT}$ in the presence of $\mathrm{Fe}^{2+}$. Under these conditions both 45 and $56 \mathrm{kDa}$ SBP form a $\mathrm{Fe}^{2+}$-containing complex with ${ }^{3} \mathrm{H}$ 5-HT (Tamir et al., 1976; Liu et al., 1985). This SBP-Fe ${ }^{2+}-{ }^{3} \mathrm{H}-$ 5 -HT complex dissociates very slowly, even in SDS. As a result, it is possible to separate the complexes from other proteins and to estimate their apparent molecular weight by PAGE (Gershon et al., 1983). When this was done with proteins extracted from MTC cells and incubated with ${ }^{3} \mathrm{H}-5-\mathrm{HT}$ in the presence of $\mathrm{Fe}^{2+}$, only one major tritiated band was detected. This protein-bound ${ }^{3} \mathrm{H}-5-\mathrm{HT}$ migrated on gels with an apparent $M_{r}$ of $45 \mathrm{kDa}$ (Fig. 7 ). No radioactivity associated with a $56 \mathrm{kDa}$ protein was detected. The 5-HT binding activity of SBP from MTC cells was characterized and its characteristics were compared with those previously reported for $45 \mathrm{kDa}$ neuronal SBP (Table 1). Like neuronal SBP, the $45 \mathrm{kDa}$ SBP from MTC cells had a high capacity to bind ${ }^{3} \mathrm{H}-5-\mathrm{HT}$ ( $60 \pm 7 \mathrm{ng} / \mathrm{mg}$ protein). As can be seen in Table 1, all of those characteristics of the binding of ${ }^{3} \mathrm{H}$ 5 -HT by MTC cell SBP that were examined were very similar 


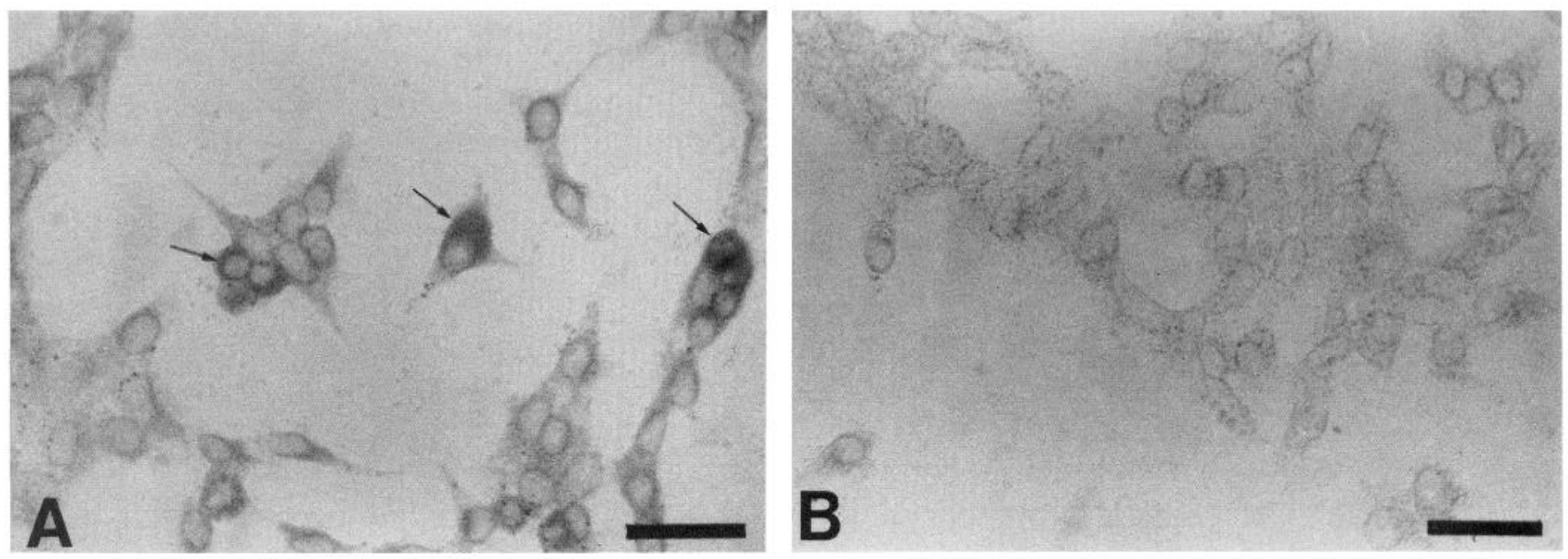

Figure 5. MAO-A immunoreactivity is observed in MTC cells grown in enriched medium. $A$, The cells were immunostained with a sheep primary antiserum specific to MAO-A followed by a biotinylated anti-sheep secondary antiserum and avidin-alkaline phosphatase. The alkaline phosphatase reaction product is found exclusively in the cytoplasm. Immunostaining is heterogeneous in intensity. Some cells $(\rightarrow)$ are very densely immunoreactive. $B$, Control. Preimmune serum was substituted for anti-MAO serum. MTC cells show little specific staining; however, there is some nonspecific granular precipitate in the cells. The cells were from cultures grown in enriched medium. Scale bars $(A$ and $B), 30 \mu \mathrm{m}$.
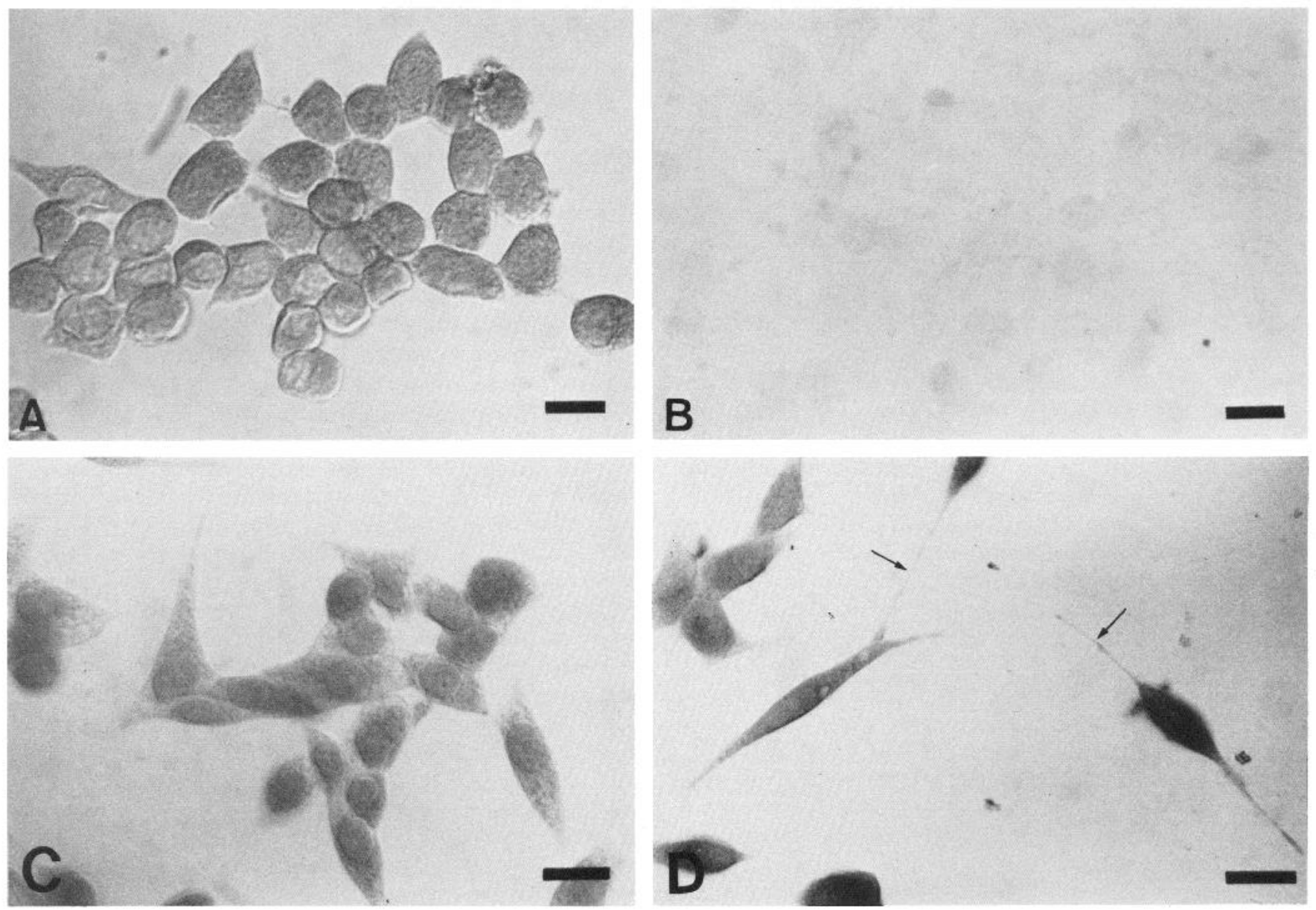

Figure 6. SBP immunoreactivity in MTC cells. $A-C$, Cells from cultures grown in enriched medium. $D$, MTC cells grown in impoverished medium (containing $1 \% \mathrm{HS}$ instead of $15 \% \mathrm{FBS}$ ). $A$, MTC cells immunostained with antiserum to $45 \mathrm{kDa}$ SBP. $B$, Control. Hippocampal neurons and glia cultured for 3 weeks. Hippocampal neurons do not contain 5-HT or SBP. There is no immunostaining with anti-45 kDa SBP sera. $C$, MTC cells immunostained with antiserum to $56 \mathrm{kDa}$ SBP. D, MTC cells from a culture grown with $1 \% \mathrm{HS}$ immunostained with antiserum to $56 \mathrm{kDa}$ SBP. Note the long processes $(\rightarrow)$ on the cells grown in the impoverished medium $(D)$. Scale bars $(A-D), 10 \mu \mathrm{m}$. 
Table 1. Comparison of the characteristics of $45 \mathrm{kDa} \mathrm{SBP}$ extracted from MTC cells with that extracted from enteric or central neurons

\begin{tabular}{|c|c|c|}
\hline Characteristic & $\begin{array}{l}\text { MTC cell } \\
\text { SBP }\end{array}$ & $\begin{array}{l}\text { Neuronal } \\
\operatorname{SBP}^{a}\end{array}$ \\
\hline Binding specificity" (\%) & 95 & 95 \\
\hline High-affinity $K_{D}$ (nM) & 8.3 & 9.7 \\
\hline Stimulation by $\mathrm{Fe}^{21}$ (-fold) & 15 & 15 \\
\hline $\mathrm{ED}_{50}$ reserpine inhibition $(\mu \mathrm{M})$ & 2.0 & 2.0 \\
\hline $\mathrm{ED}_{50}$ EDTA inhibition $(\mu \mathrm{M})$ & 1.0 & 2.0 \\
\hline $\mathrm{ED}_{50}$ inhibition by $\mathrm{SH}$ reagents $(\mu \mathrm{M})$ & 2.5 & 5.0 \\
\hline $\mathrm{ED}_{50} 5$-HTP-DP ${ }^{d}$ inhibition $(\mu \mathrm{M})$ & 2.5 & 1.0 \\
\hline$\left(\mathrm{NH}_{4}\right)_{2} \mathrm{SO}_{4}$ fraction $(\%)$ & $0-30$ & $0-30$ \\
\hline
\end{tabular}

a Tamir et al. (1976), Jonakait et al. (1977), Gershon and Tamir (1984).

"Inhibition of the binding of ${ }^{3} \mathrm{H}-5-\mathrm{HT}$ by a 100 -fold excess of nonradioactive 5-HT.

c Enhancement of the binding of ${ }^{3} \mathrm{H}-5-\mathrm{HT}$.

${ }^{d} N$-Hexanoyl-5-hydroxytryptophyl-5-hydroxytryptophan amide (Tamir and Wilchek, 1979).

to the characteristics of the binding of ${ }^{3} \mathrm{H}-5-\mathrm{HT}$ by the $45 \mathrm{kDa}$ SBP extracted from enteric or central serotonergic neurons.

\section{Effect of NGF on MTC cells}

It has previously been demonstrated that the addition of $\beta$-NGF to native sheep parafollicular cells in vitro induces them to extend neuritic processes (Barasch et al., 1987a). NGF also causes a change in alternative splicing of mRNA so that CGRP is produced instead of calcitonin. We therefore tested the effect of NGF on the morphology of the MTC cells. The addition of $\beta$-NGF $(50 \mathrm{ng} / \mathrm{ml})$ to the culture medium had no apparent effect on the morphology of MTC cells, even after 3 weeks of exposure. No neuritic processes were observed, and the intensity of the immunoreactivities of calcitonin, CGRP, and 5-HT was unchanged. Growth of MTC cells on Matrigel, rat tail collagen, or laminin, instead of plastic or glass, made no difference with respect to their responsiveness to $\beta$-NGF. A monoclonal antibody specific for the human NGF receptor (Ross et al., 1984) was used to determine if NGF receptors could be detected on MTC cells by immunocytochemistry. No NGF receptor immunoreactivity was found. In control experiments, the antibodies to human NGF receptors were found to immunostain an E9B mouse cell line that had been transfected with the human NGF receptor (Chao et al., 1986), although, as expected, the antibodies failed to immunostain nontransfected mouse $\mathrm{L}$ cells. These experiments indicate that MTC cells differ from native PF cells and lack NGF receptors.

\section{Effect on MTC cells of replacing FBS with $H S$ in the growth medium}

In an attempt to ascertain whether MTC cells are, like PF cells, capable of expressing neuronal properties, we modified the culture medium. We reasoned that the cells might continue to express an endocrine phenotype in a rich medium but might be induced to express neuronal characteristics if grown under relatively impoverished conditions. Alterations in the growth medium resulted in significant morphological and biochemical changes in the cells. The most remarkable change in the morphology was observed when $15 \%$ FBS in the medium was replaced with $1 \%$ HS. Within 10-14 d of transfer to the HScontaining medium, many of the MTC cells died; however, the

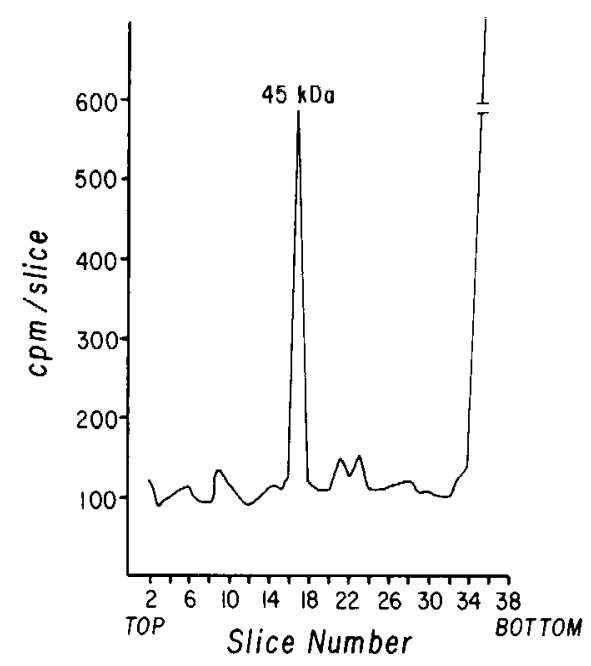

Figure 7. Analysis of SBP activity in protein extracted from MTC cells. A partially purified cell extract $(75 \mu \mathrm{g})$ was incubated with ${ }^{3} \mathrm{H}-5-$ $\mathrm{HT}$ and $\mathrm{Fe}^{2+}$. The complex, separated from free ${ }^{3} \mathrm{H}-5-\mathrm{HT}$ on Sephadex G-50, was subjected to PAGE. Gels were sliced and counted. Only a $45 \mathrm{kDa}$ protein is found to be labeled by ${ }^{3} \mathrm{H}-5-\mathrm{HT}$ under these conditions.

contour of the remaining cells changed from rounded or polyhedral to elongate or spindle shaped. Many of the MTC cells $(\sim 30 \%)$ extended varicose processes that reached several cell diameters $(150-200 \mu \mathrm{m})$ in length. Most of the cells that demonstrated such extensions displayed a single long process, but others had more than one and appeared multipolar or bipolar (Fig. 8, $A, B$ ). Individual processes tended to be shorter when cells extended more than one. Varicosities along the length of the processes as well as terminal swellings were observed. Once the MTC cells were induced in HS to extend processes, the change became permanent. Replacement of the HS-containing medium with the original medium containing $15 \%$ FBS did not cause the disappearance of the processes.

The changes in morphology induced by growth in $1 \% \mathrm{HS}$ were accompanied by cytochemical changes in the MTC cells. Little neurofilament immunoreactivity was found in the MTC cells growing in the FBS-containing control medium; however, following transfer to medium containing $1 \% \mathrm{HS}$, an increase in 150 and/or $200 \mathrm{kDa}$ neurofilament immunoreactivity was found (Fig. 9, $A, B$ ). The neurofilament immunoreactivity was most intense in the processes extended by the cells and discrete neurofilament-immunoreactive fibrils could be discerned. The impoverished medium also appeared to induce an increase in the immunoreactivity of MAO type A in MTC cells, but not of MAO type B (not illustrated). In addition, the immunoreactivities of both 45 and $56 \mathrm{kDa}$ SBP became more prominent. On the other hand, the immunoreactivity of 5-HT decreased markedly when the MTC cells were transferred from the FBS to the HS-containing medium. This change in the immunoreactivity of 5-HT was paralleled by a decrease in the concentration of 5-HT in the MTC cells measured by HPLC with electrochemical detection (to less than $20 \mathrm{pg}$ ).

\section{Effect of derivatives of $\mathrm{CAMP}$ on $M T C$ cells}

Cells were grown for one week in $15 \%$ FBS and then transferred to media containing $1 \%$ HS supplemented with one of the fol- 

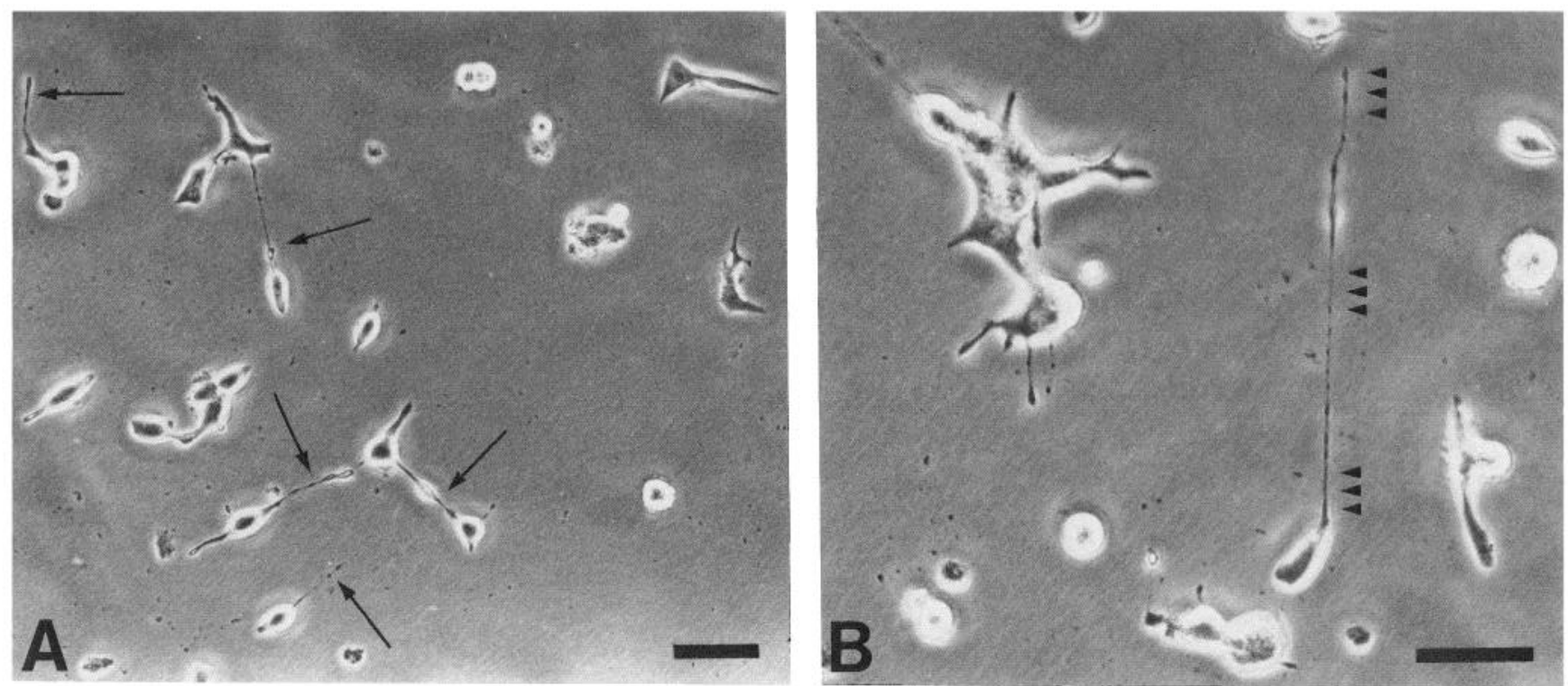

Figure 8. Phase-contrast micrographs of MTC cells grown in impoverished medium (containing $1 \%$ HS instead of $15 \%$ FBS). A, Many of the MTC cells are multipolar, extending branching, varicose processes $2-3$ cell diameters in length $(\uparrow)$. $B$, Some cells display a single, long varicose process that reaches $>200 \mu \mathrm{m}$ in length (arrowheads). Scale bars ( $A$ and $B), 50 \mu \mathrm{m}$.

lowing compounds: 8-bromo-cAMP; dibutyryl cAMP; 8-chlorophenyl cAMP (all at a concentration of $1 \mathrm{mM}$ ) both in the presence and absence of prostaglandin $\mathrm{E}_{1}(10 \mu \mathrm{g} / \mathrm{ml})$. Within 2 d most of the MTC cells rounded-up and lost their capacity to adhere to the plastic substrate. The remaining cells aggregated to form large clumps. Prolonged exposure to the derivatives of cAMP in the presence of prostaglandin $E_{1}$ caused many of the cells to die. Nevertheless, after exposure to 8-bromo-cAMP or dibutyryl cAMP for 2 weeks in the presence of prostaglandin $\mathrm{E}_{1}$, the levels of 5-HT and 5-HIAA in the surviving cells were greatly increased. The level of 5-HT was raised from $<0.2$ to $1.25 \pm 0.25 \mathrm{pmol} / \mathrm{mg}$ protein $(0.025 \pm 0.01 \mathrm{fg} /$ cell $)$, and the concentration of 5-HIAA was increased from $<0.01$ to $0.35 \pm$ $0.07 \mathrm{pmol} / \mathrm{mg}$ protein $\left(7.0 \pm 1.4 \times 10^{-3} \mathrm{fg} / \mathrm{cell}\right)$. 8-Chlorophenyl cAMP had no effect on the concentrations either of 5 -HT or of 5-HIAA. When prostaglandin $\mathrm{E}_{1}$ was omitted, the levels of 5-HT and 5-HIAA were still increased by addition of 8-bromo-cAMP or dibutyryl cAMP; however, the effect was only about half the magnitude of that seen in the presence of prostaglandin $\mathrm{E}_{1}(50 \pm 10 \% ; p<0.01 ; n=6$ cultures $)$. Forskolin $(50 \mu \mathrm{M})$ caused the cells to round up and become detached from the substrate and did not significantly affect the level of endogenous 5-HT either in the presence or absence of prostaglandin $\mathrm{E}_{1}$. Since HS, unlike FBS, has very low levels of 5-HT (Agrez et al., 1984; measured for the material used in the current experiments to be $<200 \mathrm{pg} / \mathrm{ml}$ by HPLC with electrochemical detection), the rise in the concentration of 5-HT in MTC cells induced by 8 -bromo-cAMP, dibutyryl cAMP, and prostaglandin $E_{1}$ probably reflects an increase in the biosynthesis of 5-HT.

Several other compounds known to alter phenotypic expression in cell lines were tested. These included epidermal growth factor $(20 \mathrm{ng} / \mathrm{ml})$ in conjunction with insulin $(5 \mu \mathrm{g} / \mathrm{ml})$, retinoic acid $(0.01 \mu \mathrm{M})$, and phorbol esters $(1 \mu \mathrm{M})$. No distinct morphological changes were observed, and no significant changes in 5-HT levels were detected. The changes induced in MTC cells by derivatives of cAMP therefore appeared to be relatively specific.

\section{Ultrastructure of MTC cells}

The ultrastructure of MTC cells was examined in order to gain insight into the variability encountered in the immunostaining of peptides and 5-HT in the MTC cell cultures (Fig. 10, $A, B$ ). General features of the ultrastructure of the cells were as described previously (Leong et al., 1981). MTC cells were found to resemble PF cells in that they contained secretory vesicles; however, the number of these vesicles in individual MTC cells was observed to vary widely. Many of the cells contained large numbers of secretory vesicles (Fig. 10A), while the vesicles were virtually absent in others (Fig. 10B). The vesicles were not as densely packed or as large as those of PF cells (Bernd et al., 1981; Barasch et al., 1987b). The presence of vesicles probably accounts for the granularity that was found in the immunostaining of all of the secretory products of MTC cells that were examined. It is likely that the immunoreactive material for each of these substances is stored in the secretory vesicles of the MTC cells and thus is present in highest concentration within these organelles.

\section{Discussion}

Neither central nor peripheral serotonergic neurons can be obtained for examination uncontaminated by other types of neuron. For this reason, investigators have often turned to other types of cell that might serve as models for the study of serotonergic mechanisms. The most commonly utilized of these models has been the blood platelet, because it takes up and stores 5-HT (Da Prada and Pletscher, 1968). Critical properties of platelets, however, are significantly different from those of serotonergic neurons (reviewed by Gershon and Tamir, 1984). Neurons, for example, are neurectodermal derivatives, while platelets are derived embryologically from mesoderm. Neurons synthesize 5-HT from L-tryptophan, while platelets do not and acquire their 5-HT by uptake from the surrounding medium. Platelets have a peripheral plasma membrane 5-HT binding protein, known as serotonectin, that does not associate with the 


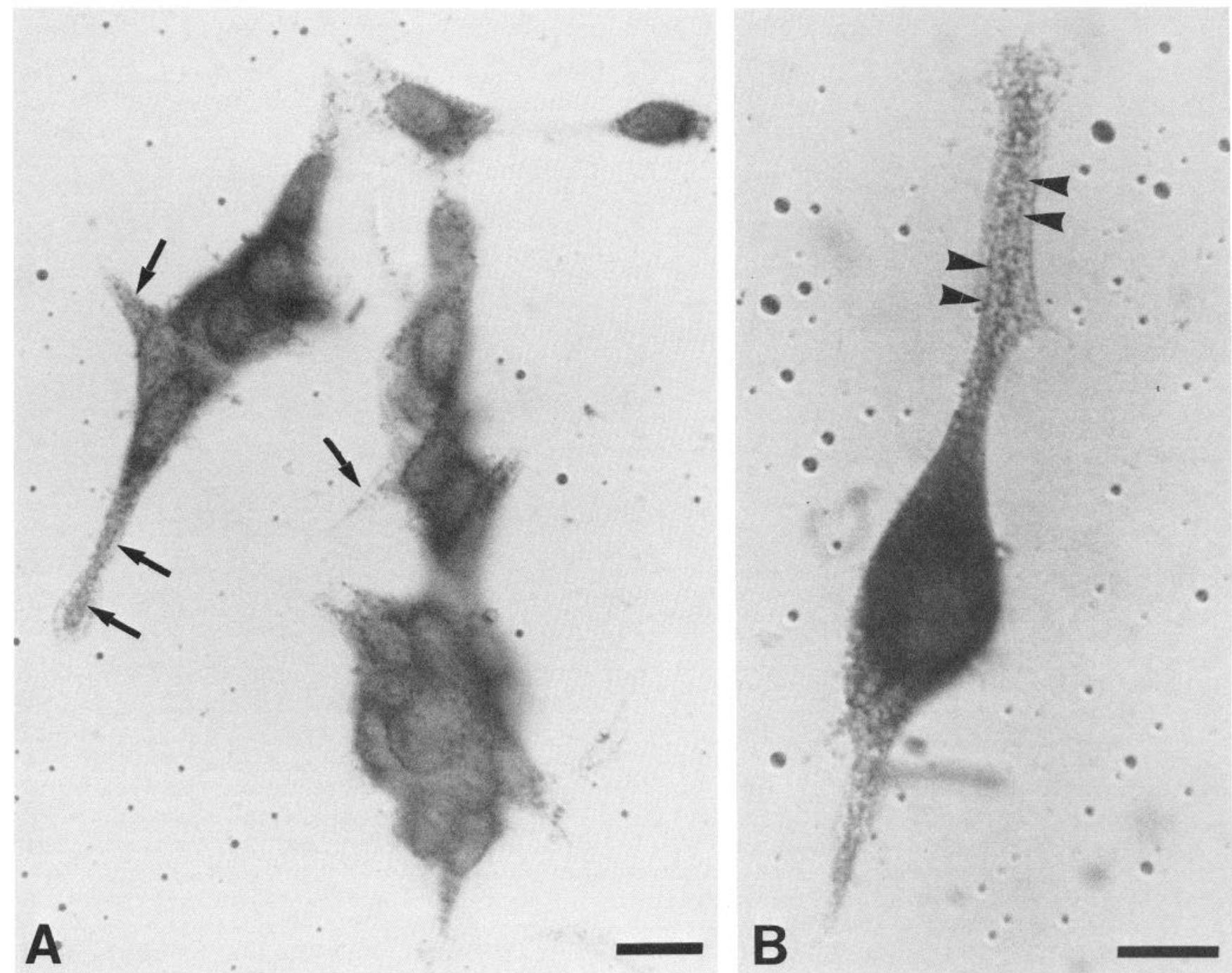

Figure 9. Neurofilament immunostaining demonstrated in MTC cells grown in impoverished medium for 2 weeks. Neurofilament immunoreactivity was visualized with a mouse monoclonal antibody that reacts with both $150 \mathrm{kDa}(\mathrm{M})$ and $200 \mathrm{kDa}(\mathrm{H})$ nonphosphorylated neurofilament proteins. Application of the primary antibody was followed by the application of a biotinylated rabbit anti-mouse secondary antiserum and avidinalkaline phosphatase. $A$, The alkaline phosphatase reaction product is visualized most intensively in a perinuclear distribution and in a fine fibrillar pattern that extends into cellular processes $(\uparrow) . B$, An MTC cell is shown at higher magnification to demonstrate the fibrillar staining pattern of the immunoreactivity within cell processes (arrowheads). Scale bars $(A$ and $B), 10 \mu \mathrm{m}$.

plasma membranes of neurons (Tamir et al., 1985; Aldersberg et al., 1986). Most significantly, the 5-HT storage organelles of platelets contain a high concentration of ATP and no SBP, while the synaptic vesicles of serotonergic neurons appear to contain relatively little ATP but they do contain SBP (Jonakait et al., 1979; Tamir and Gershon, 1979; Barasch et al., 1987b). These differences make platelets a less than adequate model for the study of serotonergic mechanisms relevant to neurons. PF cells are a better model system because, like neurons, they are neurectodermal derivatives (Pearse, 1966; Bussolati and Pearse, 1967; Le Douarin and Teillet, 1974; Polak et al., 1974; Fontaine, 1979). Like neurons, PF cells are also capable of extending neurites (Barasch et al., 1987a), they synthesize 5-HT (Nunez and Gershon, 1972), and they contain SBP (Bernd et al., 1979, 1981). Moreover, the 5-HT storage organelles of PF cells contain very little ATP and costore 5-HT in the same vesicles as 45 $\mathrm{kDa}$ SBP (Barasch et al., 1987b). The present investigation was undertaken in order to determine whether the MTC cell line, which is derived from PF cells, sufficiently mimics PF cells that it can be used for the study of neurally related serotonergic cellular mechanisms. In contrast to PF cells, MTC cells can be propagated in vitro to provide adequate amounts of material for biochemical studies.

In confirmation of previous reports (Leong et al., 1981; deBustros et al., 1986), MTC cells were found to contain a substantial number of peptides, all of which have also been reported to be present in PF cells in at least one species (Tschopp et al., 1984; Kameda et al., 1985; Nunez et al., 1988). These peptides included calcitonin, CGRP, and somatostatin, but not substance P. MTC cells also were observed to store endogenous 5-HT, to be able to synthesize 5-HT from L-tryptophan, and to take up 5-HT from the ambient medium by a carrier-mediated transmembrane transport very similar to that of serotonergic neurons. In addition, the storage of 5-HT in MTC cells was antagonized by reserpine, suggesting that the cells contain subcellular 5-HT storage organelles and that the entrance of 5-HT 

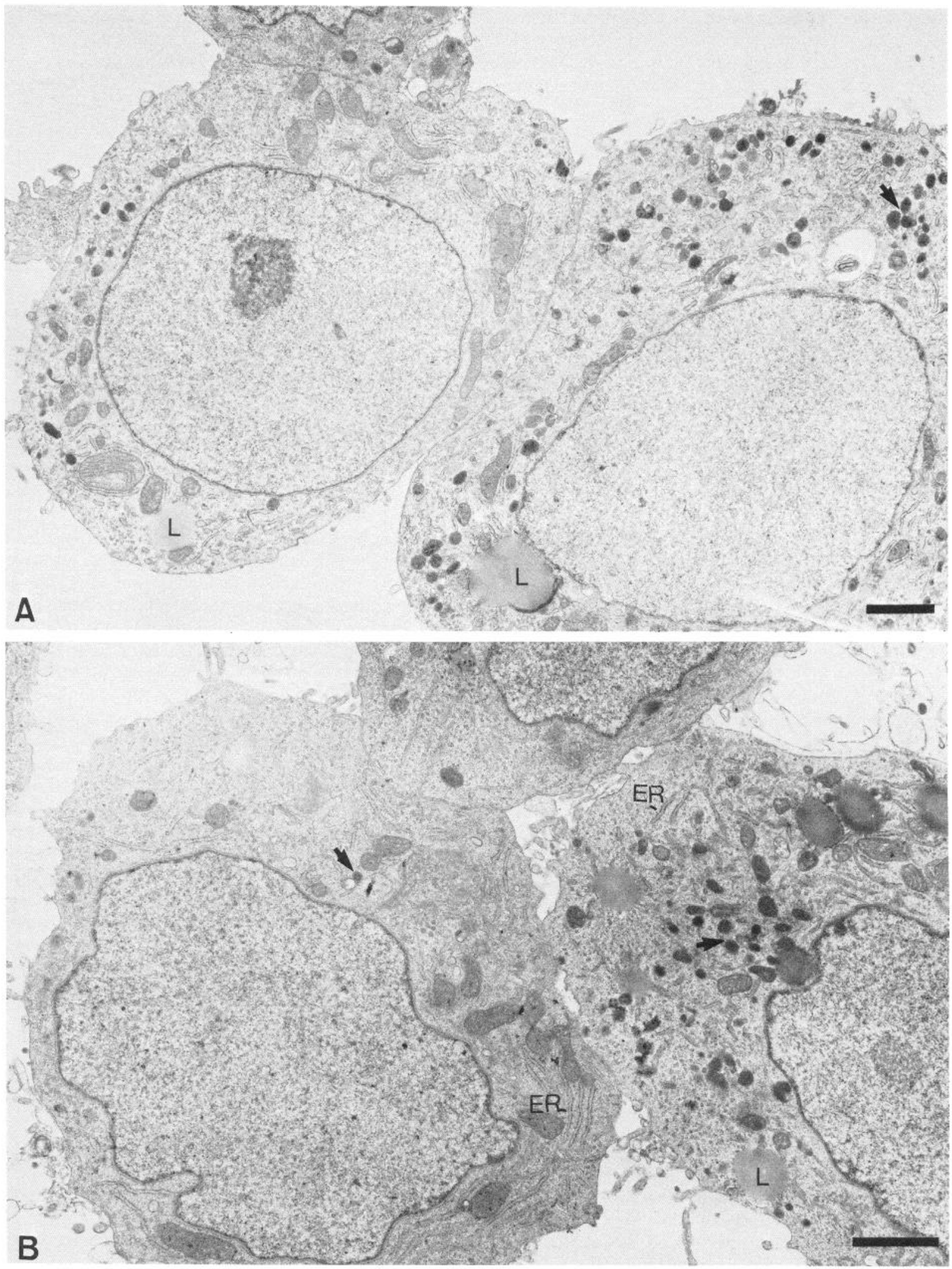

Figure 10. Electron micrographs of MTC cells grown in enriched medium for 2 weeks. Two fields are shown to depict the variation encountered in cell ultrastructure. MTC cells typically have euchromatic nuclei, large number of free polyribosomes, and scattered elements of rough endoplasmic reticulum (labeled $E R$ in $B$ ). Lipid droplets $(l)$ are frequently encountered. Cells adhere to one another as illustrated, although specialized junctions are not found. There is a striking variation in the number and size of secretory granules $(\rightarrow)$ in individual cells. Some cells contain very few granules (cell at left in $B$ ), while others contain moderate (cell at left in $A$ ) to relatively large numbers of granules (cells at right in $A$ and $B$ ). Scale bars $(A$ and $B), 1 \mu \mathrm{m}$. 
into these organelles is mediated by the reserpine-sensitive transporter of biogenic amines in the vesicular membrane. MTC cells also contain MAO, although their MAO appears to be type $A$, rather than type B. Finally, MTC cells were found to contain both 45 and $56 \mathrm{kDa}$ SBP, even though only the $45 \mathrm{kDa}$ SBP could be demonstrated to actively bind ${ }^{3} \mathrm{H}-5-\mathrm{HT}$ when extracted from the cells. MTC cells thus retain a great many of the properties of PF cells and, like PF cells, they are serotonergic cells with characteristics similar to serotonergic neurons.

MTC cells appeared to have lost some of the properties that distinguish PF cells. The most striking of these lost properties is the ability of PF cells to respond to NGF. In contrast to PF cells, MTC cells did not extend neurites when exposed to NGF. This difference in NGF responsiveness appears to be due to the absence of NGF receptors on the MTC cells, because human NGF receptors could not be demonstrated immunocytochemically on MTC cells under conditions in which these receptors were readily visualized on other cells known to express them. Nevertheless, despite the apparent absence of NGF receptors, the MTC cells do appear to be capable of at least partially expressing a neural phenotype. This expression was manifest when the cells were grown in a relatively impoverished medium, containing $1 \%$ HS instead of $15 \%$ FBS. When this was done, the cells extended neuritic processes and expressed neurofilament immunoreactivity. Moreover, exposure of MTC cells to derivatives of cAMP (8-bromo-cAMP and dibutyryl cAMP), especially in the presence of prostaglandin $E_{1}$, stimulated the expression of serotonergic properties in the cells. The ability of MTC cells to express neural properties and their expression of neuropeptides and 5-HT, which are also found in enteric neurons, supports the hypothesis that PF cells and enteric neurons develop from a common neural crest-derived precursor cell that cxprcsses an cndocrinc or a ncuronal phenotype in different embryonic microenvironments (Barasch et al., 1987a).

The mean concentration of 5-HT in MTC cells, even in cells grown in the presence of FBS, which itself contains 5-HT, appeared to be relatively low. It was estimated to be $\sim 3 \mu \mathrm{M}$. By comparison, the concentration of 5-HT in enteric serotonergic neurons grown in vitro has been estimated to be $\sim 7 \mathrm{~mm}$ (Gershon, 1982). It should be noted, however, that the cultures were very heterogeneous with respect to the 5-HT content of individual MTC cells. This heterogeneity was demonstrated by immunocytochemistry, which revealed that the intensity of 5-HT immunostaining was highly variable between cells and that some cells appeared to contain no 5-HT immunoreactivity; therefore, the estimates of the per cell concentration of $5-\mathrm{HT}$ are distorted by the restriction of 5-HT to a subset of MTC cells. The concentration of 5-HT in that subset of MTC cells that actually contains the amine is underestimated by these calculations. Nevertheless, it seems unlikely that the concentration of 5-HT in any of the MTC cells is as high as is the concentration of 5-HT in neurons. MTC cells were found to release newly synthesized $5-\mathrm{HT}$ into the medium at a faster rate than it accumulated intracellularly and there appeared to be a limit to the amount of newly synthesized 5-HT that MTC cells could store. Once this limit was reached, continued incubation with ${ }^{3} \mathrm{H}-\mathrm{L}$-tryptophan failed to increase further the amount of ${ }^{3} \mathrm{H}-5-\mathrm{HT}$ in the MTC cells. These observations suggest that the storage capacity of MTC cells for 5-HT may be lower than that of serotonergic neurons, so that the overall intracellular concentration of 5-HT is lower in the MTC cells. The relatively small storage capacity for 5-HT could be the result of a limited number of storage vesicles in MTC cells. Alternatively, MTC cells may be highly secretory and continually release vesicular contents even in the absence of secretogogues. The observation that the amount of newly synthesized 5-HT released to the medium was greater than that retained by the cells supports this possibility. Examination of the ultrastructure of MTC cells revealed that, although the cells do have vesicles, the number of these vesicles in individual cells varied and the vesicles were not as large or as densely packed as are the secretory vesicles of PF cells (Bernd et al., 1981; Barasch et al., 1987b). Since MTC cells were found to contain MAO, it seems likely that intracellular 5-HT is stored only in vesicles. The action of reserpine on the storage of 5-HT by the MTC cells supports this view. The variation between cells in the number of vesicles they contain thus appears to account for the variability that was encountered in the ability of individual MTC cells to store 5-IIT. Moreover, the relatively small number of such vesicles probably also explains the limited 5-HT storage capacity of the cells. The heterogeneity in the content of secretory vesicles may also account for the heterogeneity that was also observed between cells in their content of neuropeptides, which like 5-HT are probably stored in vesicles. A similar heterogeneity in the MTC population has previously been encountered by Berger et al. (1984), who showed that it persisted even after repeated subcloning of the cells. Further experiments are necessary to distinguish whether the variable content of vesicles in individual MTC cells reflects differences in rates of spontaneous exocytosis or differences in the production of vesicles.

The type of MAO, MAO-A, in MTC cells is noteworthy. Although 5-HT is a much better substrate for MAO-A than for MAO-B (Fowler and Callingham, 1978), serotonergic neurons in the raphe nuclei of rats and humans appear to contain MAO-B (Levitt et al., 1982; Westlund et al., 1985). On the other hand, serotonergic synaptosomes isolated from the guinea pig brain, which is thought to be similar to that of humans in this respect, metabolize 5-HT $>90 \%$ via MAO-A (Ross, 1987). In the enteric nervous system, the type of MAO found is speciesspecific. Intrinsic neurons of the guinea pig intestine contain mainly MAO-B, although the level of this enzyme in enteric serotonergic neurons is low (Sherman et al., 1987). On the other hand, enteric serotonergic neurons of the rat appear to contain MAO-A (unpublished observations). With respect to the subtype of MAO, therefore, MTC cells resemble some, but not all, serotonergic neurons, which differ in MAO subtype in different species and in different locations (Ross, 1987). Nevertheless, MTC cells are certainly capable of metabolizing 5-HT to 5-HIAA, as are neurons, and this suggests that similar mechanisms of regulating 5-HT levels may be utilized in both cell types. Several peripheral neurons or cells of peripheral neural derivation have been reported to contain $\mathrm{MAO}-\mathrm{A}$, including sympathetic neurons (Sherman et al., 1987), the chromaffin cells of the rat adrenal medulla, and PC-12 cells (Lenzen et al., 1987).

The endogenous concentration of 5-HT, as well as other properties of MTC cells, were affected by the medium in which the cells were grown. Replacing FBS with 1\% HS caused a marked decrease of 5-IIT levels. Since MTC cells take up 5-HT and HS, in contrast to FBS, contains little 5-HT, the decline in the concentration of the amine in MTC cells may reflect a decrease in intracellular amine captured from the medium, a decline in the biosynthesis of 5-HT by MTC cells, or both. Addition of either 8-bromo-cAMP or dibutyryl cAMP (in the presence of prostaglandin $E_{1}$ ) to this medium, however, markedly increased the 
concentration of 5-HT and 5-HIAA. Forskolin, on the other hand, had no effect on the concentration of 5-HT in MTC cells. The reason for the failure of forskolin to fully mimic the effect of derivatives of cAMP is not clear but has been observed previously in other systems (Coombs and Thompson, 1987). Forskolin did mimic the effects of cAMP derivatives on the morphology of MTC cells, to round up and form aggregates. The mechanism by which prostaglandin $\mathrm{E}_{1}$ potentiates the derivatives of cAMP is not clear; in some systems it has been shown to activate adenylate cyclase (Hamprecht et al., 1985). The increased levels of endogenous 5-HT following the addition of cAMP analogs in the absence of extracellular 5-HT is probably the result of stimulation of tryptophan hydroxylase activity. This may occur secondary to the phosphorylation of the enzyme by a cAMP-dependent protein kinase, as previously demonstrated in cell homogenates (Hamon et al., 1978; Kuhn et al., 1978). Other changes in MTC cells previously reported to be induced by derivatives of cAMP (added to cells grown in enriched medium) include inhibition of growth, secretion of calcitonin, and transcription of CGRP (deBustros et al., 1986).

Neurofilament proteins have not been found in the PF cells of the normal human thyroid (Dockhorn-Dworniczak et al., 1987) or sheep thyroid (Barasch et al., 1987a). On the other hand, neurofilament proteins have previously been demonstrated in some human medullary carcinomas (Dockhorn-Dworniczak ct al., 1987), but not in others (Buley et al., 1987). The acquisition of neurofilament immunoreactivity by MTC cells grown in impoverished medium thus probably represents a change in the phenotypic expression of the transformed cells that is related to their derivation from the neural crest. The morphological changes induced in MTC cells by growth in impoverished medium were accompanied by increases in the intensity of the immunoreactivities of both 45 and $56 \mathrm{kDa}$ SBP; nevertheless, despite the apparent increase in the amount of its binding protein, the concentration of 5-HT declined. Replacement of FBS with HS also caused an increase in the immunoreactivity of MAO type A; thus, the "neuron-like" MTC cells may contain less 5-HT because they more actively catabolize the amine, release it more rapidly, decrease its biosynthesis, or take up less 5-HT from the impoverished medium, which, in contrast to the enriched medium, contains virtually no 5 -HT. The MTC cells remained capable of 5-HT production in the impoverished medium, however, a capacity that was made apparent by exposing the cells to derivatives of cAMP in the presence of prostaglandin $E_{1}$. The increase in SBP immunoreactivity in the face of a decline in endogenous 5-HT suggests that the regulation of the biosynthesis of the binding protein is independent of the 5-HT concentration. In contrast to PF cells, which express CGRP in preference to calcitonin when induced to extend neurites, no changes in the immunoreactivities of either calcitonin or CGRP were noted in the neuron-like MTC cells. Although similar in many critical characteristics, MTC cells thus differ from the PF cells from which they were derived in many of their responses to environmental perturbations. Such differences are to be expected in a transformed cell line. Despite these differences, it may be concluded that MTC cells are an excellent model to use for the study of serotonergic mechanisms relevant to neurons.

\section{References}

Adlersberg, M., K. P. Liu, and H. Tamir (1986) Human serotonectin: A blood glycoprotein that binds serotonin. Chemical and physiological characterization. Biochem. Biophys. Acta 880: 139-146.
Agrez, M. V., M. M. Ames, M. M. Lieber, and G. M. Tyce (1984) The presence of serotonin in animal sera used in cultures. Biogenic Amines 1: 223-228.

Barasch, J. M., H. Mackey, H. Tamir, E. A. Nunez, and M. D. Gershon (1987a) Induction of a neural phenotype in a serotonergic endocrine cell derived from the neural crest. J. Neurosci. 7: 2874-2883.

Barasch, J. M., H. Tamir, E. A. Nunez, and M. D. Gershon (1987b) Serotonin-storing secretory granules from thyroid parafollicular cells. J. Neurosci. 7: 4017-4033.

Baylin, S. B., and G. Mendelssohn (1980) Ectopic (inappropriate) hormone production by tumors: Mechanisms involved and the biological and clinical implications. Endocrinol. Rev. 1: 45-51.

Berger, C. L., A. deBustros, B. A. Roos, S. S. Leong, G. Mendelssohn, M. S. Gesell, and S. B. Baylin (1984) Human medullary thyroid carcinoma in culture provides a model relating growth dynamics, endocrine cell differentiation, and tumor progression. J. Clin. Endocrinol. Metab. 59: 338-343.

Bernd, P., M. D. Gershon, E. A. Nunez, and H. Tamir (1979) Localization of a highly specific binding protein to serotonin in thyroid parafollicular cells. Anat. Rec. 19: 257-268.

Bernd, P., M. D. Gershon, E. A. Nunez, and H. Tamir (1981) Separation of dissociated thyroid follicular and parafollicular cells: Association of serotonin binding protein. J. Cell Biol. 88: 499-508.

Buley, I. D., K. C. Gatter, A. Heryet, and D. Y. Mason (1987) Expression of intermediate filament proteins in normal and diseased thyroid glands. J. Clin. Pathol. 40: 136-142.

Bussolati, G., and A. G. E. Pearse (1967) Immunofluorescent localization of calcitonin in the C-cells of pig and dog thyroid. J. Endocrinol. 37: 205-209.

Carlsson, A. (1965) Drugs that block the storage of 5-hydroxytryptamine and related amines. Handbook Exp. Pharmacol. 19: 529-592.

Chao, M. V., M. A. Bothwell, A. H. Ross, H. Koprowski, A. A. Lanahan, C. R. Buck, and A. Sehgal (1986) Gene transfer and molecular cloning of the human NGF receptor. Science 232: 518-521.

Coombs, J., and S. Thompson (1987) Forskolin effect on transient $\mathrm{K}^{+}$ current in nudibranch neurons is not reproduced by cAMP. J. Neurosci. 7: 443-452.

Costa, M., J. B. Furness, and I. J. Llewellyn-Smith (1987) Histochemistry of the enteric nervous system. In Physiology of the Gastrointestinal Tract, Vol. 1, L. R. Johnson, J. Christensen, M. J. Jackson, E. D. Jacobson, and J. H. Walsh, eds., Raven, New York.

Cuatrecasas, P., M. Wilchek, and C. B. Anfinsen (1968) Selective enzyme purification by affinity chromatography. Proc. Natl. Acad. Sci. USA 61: 636-643.

Da Prada, M., and A. Pletscher (1968) Isolation of 5-hydroxytryptamine organelles of rabbit blood platelets: Physiological properties and drug induced changes. Br. J. Pharmacol. 34: 591-597.

deBustros, A., S. B. Baylin, M. A. Levine, and B. D. Nelkin (1986) Cyclic AMP and phorbol esters separately induce growth inhibition, calcitonin secretion, and calcitonin gene transcription in cultured human medullary thyroid carcinoma. J. Biol. Chem. 26I: 8036-8041.

Dockhorn-Dworniczak, B., W. W. Franke, S. Schroder, B. Czernobilsky, V. E. Gould, and W. Bocker (1987) Patterns of expression of cytoskeletal proteins in human thyroid gland and thyroid carcinoma. Differentiation 35: 53-71.

Falck, B., B. Larson, C. V. Mecklenburg, E. Rosengren, and K. Svenaeous (1964) On the presence of a second specific ccll systcm in mammalian thyroid gland. Acta Physiol. Scand. 62: 491-492.

Fontaine, J. (1979) Multistep migration of calcitonin cell precursors during ontogeny of the mouse pharynx. Gen. Comp. Endocrinol. 37: 81-91.

Fowler, C. J., and B. A. Callingham (1978) Substrate-selective activation of rat liver mitochondria monoamine oxidase by oxygen. Biochem. Pharmacol. 27: 1995-2000.

Fujita, T. (1977) Concept of paraneurons. Arch. Histol. Jpn. (Suppl.) 40: $1-12$.

Gershon, M. D. (1977) Biochemistry and physiology of serotonergic transmission. In Handbook of Physiology, J. M. Brookhart, V. B. Mountcastle, E. R. Kandel, and S. R. Geiger, eds., pp. 573-623, Am. Physiol. Soc., Bethesda, MD.

Gershon, M. D. (1982) Enteric scrotonergic neurons. In Biology of Serotonergic Neurotransmission, N. Osborne, ed., pp. 363-399, Wiley, New York.

Gershon, M. D., and E. A. Nunez (1970) Histochemical and radioautographic studies of serotonin and parafollicular cells in the thyroid gland of the prehibernating bat. Endocrinology 86: 160-166. 
Gershon, M. D., and H. Tamir (1984) Serotonectin and the family of proteins that bind serotonin. Biochem. Pharmacol. 33: 3115-3118.

Gershon, M. D., K. P. Liu, S. E. Karpiak, and H. Tamir (1983) Storage of serotonin in vivo as a complex with serotonin binding protein in central and peripheral serotonergic neurons. J. Neurosci. 3: 19011911.

Hamon, M., S. Bourgoin, F. Hery, and G. Simonnet (1978) Activation of tryptophan hydroxylase by ATP, magnesium and calcium. Mol. Pharmacol. 14: 99-110.

Hamprecht, B., T. Glaser, G. Reiser, E. Bayer, and F. Probst (1985) Culture and characteristics of hormone-responsive neuroblastoma $\times$ glioma hybrid cells. Methods Enzymol. 109: 316-341.

Itoh, K., A. Konishi, S. Nomura, N. Mizuno, Y. Nakamura, and T. Sugimoto (1979) Application of coupled oxidation reaction to electron microscopic demonstration of horseradish peroxidasc: Cobaltglucose oxidase method. Brain Res. 175: 341-346.

Jaim-Etcheverry, G., and L. M. Zeiher (1968) Cytochemical localization of monoamine stores in sheep thyroid gland at the electron microscope level. Experientia 24: 593-596.

Johnson, R. G., Jr. (1988) Accumulation of biological amines into chromaffin granules: A model for hormone and neurotransmitter transport. Physiol. Rev. 68: 232-307.

Johnston, J. P. (1968) Some observations upon a new inhibitor of monoamine oxidase in brain tissue. Biochem. Pharmacol. 17: 12851297.

Jonakait, J. M., H. Tamir, M. M. Rapport, and M. D. Gershon (1977) Detection of a soluble serotonin binding protein in mammalian myenteric plexus and other peripheral sites of serotonin storage. J. Neurochem. 28: 277-284.

Jonakait, J. M., H. Tamir, A. R. Gintzler, and M. D. Gershon (1979) Release of serotonin and its binding protein by enteric neurons. Brain Res. 174: 55-69.

Jonakait, J. M., A. R. Gintzler, and M. D. Gershon (1979) Isolation of axonal varicosities (autonomic synaptosomes) from the enteric nervous system. J. Neurochem. 32: 1387-1400.

Kameda, Y., M. Ito, K. Ogawa, and T. Tagawa (1985) Alteration of immunoreactive somatostatin in thyroid $\mathrm{C}$ cells. An immunohistochemical study. Virchow's Arch. [A] 410: 97-101.

Kirchgessner, A. L., M. D. Gershon, K. P. Liu, and H. Tamir (1988) Costorage of serotonin binding protein with serotonin in the rat CNS. J. Neurosci. 8: 3879-3890.

Knoll, J., and K. Magyar (1972) Some puzzling pharmacological effects of monoamine oxidase inhibitors. Adv. Biochem. Psychopharmacol. 5: $393-408$

Kuhn, D. M., R. L. Vogel, and W. Lovenberg (1978) Calcium dependent activation of tryptophan hydroxylase by ATP and magnesium. Biochem. Biophys. Res. Commun. 82: 759-766.

Le Douarin, N. M. (1982) The Neural Crest, Cambridge U. P., London.

Le Douarin, N. M., and M. A. Teillet (1974) Experimental analysis of the migration and differentiation of neuroblasts of the autonomic nervous system and of neurectodermal mesenchymal derivatives using a biological marker technique. Dev. Biol. 41: 162-184.

Lenzen, S., M. Freisinger-Treichel, and U. Panten (1987) Monoamine oxidase in rat and bovine endocrine tissues. J. Neurochem. 49:11831190.

Leong, S. S., J. S. Horoszewicz, K. Shimaoka, M. Friedman, E. Kawinski, M. J. Song, R. Zcigcl, T. M. Chu, S. Baylin, and E. A. Mirand (1981) A new cell line for the study of human medullary thyroid carcinoma. In Advances in Thyroid Neoplasia, M. Andreoli, F. Monaco, and J. Robbins, eds., pp. 95-108, Field Educational Italia, Rome.

Levitt, P., J. E. Pintar, and X. O. Breakefield (1982) Immunocytochemical demonstration of monoamine oxidase $B$ in brain astrocytes and serotonergic neurons. Proc. Natl. Acad. Sci. USA 79: 6385-6389.

Liu, K. P., M. D. Gershon, and H. Tamir (1985) Identification, purification and characterization of serotonin binding protein from rat brain. J. Neurochem. 44: 1289-1301.

Liu, K. P., H. Tamir, S. Hsiung, M. Adlersberg, and M. D. Gershon (1987) Prenatal development of serotonin binding protein in relation to other transmitter-related characteristics of central serotonergic neurons. Dev. Brain Res. 32: 1-41.

Machado, C. R. S. (1976) Monoamines in the C cells of the thyroid gland of callithricid primates. Histochemistry 48: 187-190.

Neff, N. H., and H. Y. Yang (1974) Another look at the monoamine oxidase and the monoamine oxidase drugs. Life Sci. 14: 2061-2074.

Nunez, E. A., and M. D. Gershon (1972) Synthesis and storage of serotonin by parafollicular (C) cells of the thyroid gland of active, prehibernating and hibernating bats. Endocrinology 90: 1008-1024.

Nunez, E. A., R. F. Payette, H. Tamir, and M. D. Gershon (1988) Ultrastructural immunocytochemical studies of the localization and distribution of somatostatin, calcitonin, calcitonin gene-related peptide and substance $\mathrm{P}$ in the bat thyroid follicle. Anat. Rec. 221: 707713.

Payette, R. F., M. D. Gershon, and E. A. Nunez (1985) Serotonergic elements of the mammalian pituitary. Endocrinology 116: 1933-1942.

Pearse, A. G. E. (1966) Common cytochemical properties of cells producing polypeptide hormones, with particular reference to calcitonin and the thyroid C cells. Vet. Rec. 79: 587-590.

Pearse, A. G. E., J. M. Polak, F. W. E. Rost, I. Fontaine, C. Le Lievre, and N. M. Le Douarin (1973) Demonstration of the neural crest origin of type 1 (APUD) cells in the avian carotid body using a cytochemical marker system. Histochemistry 34: 191-203.

Polak, J. M., A. G. E. Pearse, C. Le Lievre, J. Fontaine, and N. M. Le Douarin (1974) Immunocytochemical confirmation of the neural crest origin of avian calcitonin-producing cells. Histochemistry 40: 209-214.

Ponder, B. A., and M. M. Wilkinson (1981) Inhibition of endogenous tissue alkaline phosphatase with the use of alkaline phosphatase conjugates in immunohistochemistry. J. Histochem. Cytochem. 29:981984.

Reinhard, J. F., M. A. Moskowitz, A. F. Sved, and J. D. Fernstorm (1980) A simple, sensitive and reliable assay for serotonin and 5-HIAA in brain tissue using liquid chromatography with electrochemical detection. Life Sci. 27: 905-911.

Ross, A. H., P. Grob, M. Bothwell, D. E. Elder, C. S. Ernst, N. Marano, B. F. D. Ghrist, C. Slamp, M. Herlyn, B. Atkinson, and H. Koprowski (1984) Characterization of nerve growth factor receptor in neural crest tumors using monoclonal antibodies. Proc. Natl. Acad. Sci. USA 81: 6681-6685.

Ross, S. B. (1982) The characteristics of serotonin uptake systems. In Biology of Serotonergic Transmission, N. N. Osborne, ed., pp. 159195, Wiley, New York.

Ross, S. B. (1987) Distribution of two forms of monoamine oxidase within monoaminergic neurons of the guinea pig brain. J. Neurochem. 48: 609-614.

Sah, D. W. Y., and S. G. Matsumoto (1987) Evidence for serotonin synthesis, uptake, and release in dissociated rat sympathetic neurons in culture. J. Neurosci. 7: 391-399.

Sherman, D., J. Pintar, and M. D. Gershon (1987) Location of monoamine oxidase (MAO) types $A$ and $B$ in the enteric nervous system of the guinea pig small intestine. Soc. Neurosci. Abstr. 13: 1671.

Shie, J. C., and S. Eiduson (1973) Monoamine oxidase: Isolation and characterization of multiple forms of the brain enzyme. J. Neurochem. 21: $41-49$.

Slotkin, T., F. Seidler, W. Whitmore, C. Lau, M. Salvaggio, and D. Kirksey (1978) Rat brain synaptic vesicles: Uptake specificity of $\left({ }^{3} \mathrm{H}\right)$ norepinephrine and $\left({ }^{3} \mathrm{H}\right)$ serotonin in preparation from whole brain and brain regions. J. Neurochem. 31: 961-968.

Steinbusch, H. W. M., A. A. J. Verhofstad, and H. W. J. Joosten (1978) Localization of serotonin in the central nervous system by immunohistochemistry: Description of a specific and sensitive technique and some applications. Neuroscience 3: 811-819.

Tamir, H. (1982) Serotonin binding proteins. J. Histochem. Cytochem. 30:837-840.

Tamir, H., and M. D. Gershon (1979) Storage of serotonin binding protein in synaptic vesicles. J. Neurochem. 33: 35-44.

Tamir, H., and M. Wilchek (1979) 5-Hydroxytryptophyl peptides: Potent inhibitors of a storage compartment of serotonin. J. Neurochem. 32: 593-598.

Tamir, H., A. Klein, and M. M. Kapport (1976) Serotonin binding protein: Enhancement of binding by $\mathrm{Fe}^{2+}$ and inhibition of binding by drugs. J. Neurochem. 26: 871-878.

Tamir, H., R. F. Payette, Y. L. Huang, K. P. Liu, and M. D. Gershon (1985) Human serotonectin: A blood glycoprotein that binds serotonin and is associated with platelets and white blood cells. J. Cell Sci. 73: 187-206.

Tschopp, F. A., P. H. Tobler, and J. A. Fischer (1984) Calcitonin gene-related peptide in the human thyroid, pituitary and brain. Mol. Cell Endocrinol. 36: 53-57.

Westlund, K. N., R. M. Kenney, R. M. M. Rose, and C. W. Abell (1985) MAO A in catecholaminergic and MAO B in serotonergic regions: Immunocytochemical localization in human brain. Soc. Neurosci. Abstr. 11: 1018 . 